\title{
An exploratory analysis on the toxicity \& safety profile of Polyherbal combination of curcumin, quercetin and rutin
}

\author{
Reshu Tiwari ${ }^{1,2}$, Mohammed Haris Siddiqui ${ }^{3 *}$, Tarique Mahmood ${ }^{4}$, Alvina Farooqui ${ }^{3}$, Paramdeep Bagga 5 , \\ Farogh Ahsan ${ }^{4}$ and Arshiya Shamim ${ }^{4}$
}

\begin{abstract}
Background: Curcumin, quercetin and rutin are flavonoids having strong antioxidant potential, individually used in treatment of numerous ailments. The safety assessment of each of them is already established but no toxicological assessment has been done that would guarantee the safe use of these three flavonoids when used as a polyherbal combination (PHC). The aim of this study to evaluate the possible toxicological effect of polyherbal combination of these three flavonoids in female Swiss albino mice.

Methods: In acute toxicity study, the oral dose of poly herbal combination was administered to four groups stepwise in single dose and general behaviour, adverse effects and mortality were determined up to 14 days and compared to normal group. In sub-acute study, the tested poly herbal combination was administered orally for 28 days to the four experimental groups and their body weight was measured each alternate day from the first day of dosing. On 29th day the final body weight was recorded and euthanized by using thiopentone sodium, blood was collected and later haematological, lipid profile, biochemical parameter was evaluated and compared to normal group.
\end{abstract}

Result: In acute toxicity study, no abnormal general behaviour, adverse effects were reported. No significant changes were reported in body weight, haematological, lipid profile, biochemical parameter in sub-acute toxicity study. No mortality was reported in both the study. Histopathological examination revealed no alterations in clinical signs or organ weight at any dose.

Conclusion: The result concludes that the oral administration of Polyherbal combination did not produce any significant toxic effect in swiss albino mice. Hence, the Polyherbal combination can be utilized safely for therapeutic use.

Keywords: Curcumin, Quercetin, Rutin, Acute toxicity study, Sub-acute toxicity study

\section{Introduction}

Natural resources and their derivatives are the most common sources of bioactive molecules in medicines since the evolution of other advanced therapeutics in the post-genomic era. World Health Organization (WHO) describe traditional herbal medications as naturally

\footnotetext{
* Correspondence: siddiquimohdharis@gmail.com

${ }^{3}$ Department of Bioengineering, Faculty of Engineering, Integral University, Lucknow, India

Full list of author information is available at the end of the article
}

occurring, plant-derived materials with negligible or no industrial processing which have been utilized to treat ailment within regional or local healing practices [1]. Traditional system of medicine and their formulations have been extensively used since many years in developed and developing countries mainly due to its natural origin and minor side effects [2]. Herbal medicine is in the mainstream of around $75-80 \%$ of the world population, primarily in the developing countries, for use in primary health care. This is mostly because of the

\section{Springer Open}

(c) The Author(s). 2020, corrected publication 2021. Open Access This article is licensed under a Creative Commons Attribution 4.0 International License, which permits use, sharing, adaptation, distribution and reproduction in any medium or format, as long as you give appropriate credit to the original author(s) and the source, provide a link to the Creative Commons licence, and indicate if changes were made. The images or other third party material in this article are included in the article's Creative Commons licence, unless indicated otherwise in a credit line to the material. If material is not included in the article's Creative Commons licence and your intended use is not permitted by statutory regulation or exceeds the permitted use, you will need to obtain permission directly from the copyright holder. To view a copy of this licence, visit http://creativecommons.org/ licenses/by/4.0/. 
universal belief that herbal medicines don't have any side effects in addition being locally available and cheap [3].

A toxicological examination is well-thought-out to be very important for the discovery of new drugs. The regulatory authority, Food and Drug Administration (FDA) have specified that it is significant to screen new molecules for their toxicity profile and pharmacological action in animals [4]. Many developing nations are using herbs and aromatic plants and their formulations for their health care requirements. In fact, about $25 \%$ of allopathic medicines are derived from natural sources especially plants which are being utilized for the treatment of numerous diseases in throughout the globe. Ayurvedic and Unani system of medicine is still effectively practiced in India where roughly $85 \%$ of the Indian populace uses crude plant extract or their formulations for the treatment of several ailments [5].

The toxicity study is a non-clinical safety evaluation process which is done to generate information about the toxicological properties of test compounds. The aim of studying toxicity screening of any compounds is to confirm the safety of the chemical substances before they can be utilized as test drugs during the process of clinical trials [6].

Acute and subacute toxicity examination of medicinal plants are the most rapid ways to estimate the toxicological nature of any medicinal plants [7].

Herbal drug combinations have shown that they possess better efficacy and reduced side-effects in comparison with individual herbal drugs. Detailed pharmacological examinations using molecular biological assays have discussed assuming the better efficacy might be due to additive or potentiated synergistic effects caused by the individual components of the combination. The medicative uses of three phytochemicals with completely different purity (curcumin, quercetin and rutin) have been well documented within the literature. One amongst most studied natural resources measure is flavonoids that represent a wide cluster of secondary metabolites and located principally in many edible fruits and is consumed as a part of day to day dietary habits [8].

The term flavonoid describes numerous plant-derived compounds distributing by a standard skeleton of phenylchromane [9]. This basic structure permits thousands of substitution patterns resulting in many flavonoid subclasses like flavanols, flavones, flavanones, anthocyanidins, isoflavones, dihydroflavonols, catechins and chalcones. These compounds area unit usually distributed within the plant, and plant product like dietary fruits, vegetables, nuts, seeds, herbs and spices [10]. Recently, the interest in dietary flavonoids has raised significantly credit goes to their inhibitor, such as antiviral, antibacterial drug, medicament and anticarcinogenic activities [11, 12]. Their probable role in preventing pathologies related to aerophilous stress, like necrosis and neurodegenerative diseases.

Flavonoids generally use their inhibitor activity by completely different mechanisms, like by scavenging or extinction free radicals, by chelating metal ions, or by inhibiting protein systems accountable for the generation of free radical [13, 14]. Curcumin [1,7-bis-(4-hydroxy-3-methoxyphenyl)-1,6-heptadiene- three,5-dione] could be a natural flavonoid element found within the rootstock of herb (Zingiberaceae or ginger family). Many studies have reported that the curcumin, act as medicament, chemotherapeutical, and antinociceptive agent $[15,16]$. The acute toxicity, repeated dose toxicity and mutagenicity examination, revealed that curcumin is deemed to be safe and non-toxic [17]. In another study, the toxicology study revealed that the curcumin does not displayed any toxicity sign when administered up to a dose of $500 \mathrm{mg} / \mathrm{kg}$ and $5000 \mathrm{mg} / \mathrm{kg}$ respectively [18, 19]. One more toxicity study revealed that consumption of curcu$\mathrm{min}$ at dose of $2000 \mathrm{mg} / \mathrm{kg}$ does not displayed any other toxicity symptoms neither mortality reported [20].

The other polyphenolics compounds of flavonoids such as quercetin and rutin are present in different types of fruits, vegetables, tea, coffee, red wine, beer and variety of medicative plants and their parts such as leaves, seeds, flowers etc. [21, 22]. Rutin is a flavanol found in various plant. It is also termed as vitamin P. It is watersoluble and it get converted into quercetin when it enters the blood stream. The single and repeated dose toxicity study of rutin revealed that it is non-toxic up to $5000 \mathrm{mg} / \mathrm{kg}$ [23]. The sub chronic toxicity screening of enzymatically decomposed rutin inform that it is safe for future use [24]. Another study revealed that rutin is safe up to $2000 \mathrm{mg} / \mathrm{kg}$ [25]. Quercetin is a flavonoid obtained from fruit and vegetable [26]. The in-vivo and in-vitro genotoxicity, Acute, Subchronic and chronic toxicity and carcinogenicity studies of quercetin exposed that at predictable dietary intake levels, it does not result in adverse health effects [27]. One more study state that rutin does not displayed any toxicity sign up to $2000 \mathrm{mg} / \mathrm{kg}$ [28]. According to many studies these flavonoids have antiinflammatory [29-31], analgesic [32], and inhibitor [33] effects.

This study was aimed to get the safety profile of polyherbal combination (PHC) of natural origin drug (quercetin, rutin and curcumin) and also to obtain a no observed adverse effect level (NOAEL) according to OECD 425 and 407 respectively [34, 35]. The purpose of analysing toxicity effect is to provide acceptable database to make conclusions concerning the toxicology nature of chemical. After through analysis of literature, it was observed that the toxicity study of individual components of these polyherbal combinations has been already 
performed several times, but no toxicity study has been performed for the combination of these three flavonoids, so the safety profile was estimated, drawing hypothesis as individually they are safe but the combination can show some toxic effect or it may be safe too. Thus, the toxicity study of PHC will open the safety profile windows, providing information that the $\mathrm{PHC}$ of following drugs are safer or not and this information may be used in formulation of various dosage form of these polyherbal combination.

\section{Materials and methods}

\section{Chemicals and test material}

Curcumin, Quercetin and Rutin were purchased from Sissco Research Laboratories Pvt. Ltd. Mumbai, India. All other reagents were used of analytical grade and were supplied by local suppliers, Shubh scientific, Lucknow.

\section{Experimental animal}

Young healthy swiss albino mice, four weeks old, of body weight $18-22 \mathrm{~g}$ were utilized in this study. The animals were purchased from animal house facility of Central Drug Research Institute (CDRI), Lucknow. The animals were maintained underneath customary environmental conditions $\left(23^{\circ} \mathrm{C}-25^{\circ} \mathrm{C}, 12 \mathrm{~h} / 12 \mathrm{~h}\right.$ light / dark cycle) and provided standard pelleted diet (Dayal food pvt ltd, Unnao) and water ad libitum. All the animals were habituated to laboratory atmosphere for a week before study proceeded.

\section{Experimental design}

\section{Dose calculation}

The different dose combinations of polyherbal combination (PHC) were selected for the toxicity studies on the data providing $\mathrm{ED}_{50}$ value and toxicological profiling of each individual drugs based on the various earlier research $[20,25,28]$. The doses were selected according to OECD guideline protocol, assuming the best estimate of $\mathrm{LD}_{50}$ as no data related to dose of the this polyherbal combination was mentioned in literature, the dose progression was calculated according to geometric ratio of $1 / 2$ (double the initial dose to get next dose) [36] i.e. $(250 \mathrm{mg} / \mathrm{kg} / \mathrm{day}, \quad 500 \mathrm{mg} / \mathrm{kg} /$ day, $\quad 1000 \mathrm{mg} / \mathrm{kg} /$ day and $2000 \mathrm{mg} / \mathrm{kg} /$ day) were selected for acute and sub-acute toxicity study. The dose of polyherbal combination which was administered in the individual mice in each experimental group was calculated on the basis of body weights (Table 1 ).

\section{Drug administration}

The oral route was selected for the administration of PHC directly into the stomach, via a gavage needle. For acute toxicity study, the animals were fasted nightlong for around $16 \mathrm{~h}$ before dosing. Drinking water ad libitum and feed was provided, about $4 \mathrm{~h}$ once dosing [37]. Within the sub-acute toxicity study PHC was administered by oral route once every day for 28 days without fasting [38].

\section{Acute toxicity study}

The OECD guideline (OECD 425) was followed for evaluation of acute toxicity study. Female swiss albino mice (4week old) (18-22 g) were divided into five groups, each comprising 5 animals. The first group present as a normal control group (NC) and received normal saline, while 2 nd, $3 \mathrm{rd}$, 4th and 5th was considered as toxic groups received $\mathrm{PHC}$ (dissolved in distilled water) orally once at a dose of $250 \mathrm{mg} / \mathrm{kg} /$ p.o. (TG1), $500 \mathrm{mg} / \mathrm{kg} /$ p.o. (TG2), $1000 \mathrm{mg} /$ $\mathrm{kg} / \mathrm{p}$.o. (TG3) and $2000 \mathrm{mg} / \mathrm{kg} /$ p.o. (TG4). The dosing was started from lower dose $(250 \mathrm{mg} / \mathrm{kg})$, if all animal survive then next highest dose was given, like this the experiment was carried out till highest dose up to $2000 \mathrm{mg} / \mathrm{kg}$. All animals were remarked for clinical sign, behavioural changes and other different parameters like body weight,

Table 1 Dosing protocol of polyherbal combination (PHC) to female swiss albino mice for acute and sub-acute toxicity study

\begin{tabular}{cllc}
\hline S.No & Group name & Group detail & Dosing schedule \\
\hline Acute toxicity study & & & Normal Saline \\
1 & NC & Normal Control of acute toxicity study & $250 \mathrm{mg} / \mathrm{kg} / \mathrm{day} / \mathrm{p} .0$ \\
2 & TG1 & Acute toxicity group 1 & $500 \mathrm{mg} / \mathrm{kg} / \mathrm{day} / \mathrm{p} .0$ \\
3 & TG2 & Acute toxicity group 2 & $1000 \mathrm{mg} / \mathrm{kg} / \mathrm{day} / \mathrm{p} .0$ \\
4 & TG3 & Acute toxicity group 3 & $2000 \mathrm{mg} / \mathrm{kg} / \mathrm{day} / \mathrm{p} .0$ \\
5 & TG4 & Acute toxicity group 4 & \\
Sub-acute toxicity study & & & Normal Saline \\
1 & NCX & Normal Control of sub-acute toxicity study & $250 \mathrm{mg} / \mathrm{kg} / \mathrm{day} / \mathrm{p} .0$ \\
2 & TX1 & Sub-acute toxicity group 1 & $500 \mathrm{mg} / \mathrm{kg} / \mathrm{day} / \mathrm{p} .0$ \\
3 & TX2 & Sub-acute toxicity group 2 & $1000 \mathrm{mg} / \mathrm{kg} / \mathrm{day} / \mathrm{p} .0$ \\
4 & TX3 & Sub-acute toxicity group 3 & $2000 \mathrm{mg} / \mathrm{kg} / \mathrm{day} / \mathrm{p} .0$ \\
5 & TX4 & Sub-acute toxicity group 4 & \\
\hline
\end{tabular}


Table 2 Effect of polyherbal combination (PHC) on physical and behavioral parameter in mice during 14-day acute toxicity study

\begin{tabular}{|c|c|c|c|c|c|}
\hline Parameter & $\begin{array}{l}\text { Normal control } \\
\text { NC }\end{array}$ & $\begin{array}{l}250 \mathrm{mg} / \mathrm{kg} / \text { day } \\
\text { TG1 }\end{array}$ & $\begin{array}{l}500 \mathrm{mg} / \mathrm{kg} / \text { day } \\
\text { TG2 }\end{array}$ & $\begin{array}{l}1000 \mathrm{mg} / \mathrm{kg} / \mathrm{day} \\
\text { TG3 }\end{array}$ & $\begin{array}{l}2000 \mathrm{mg} / \mathrm{kg} / \mathrm{day} \\
\text { TG4 }\end{array}$ \\
\hline Body weight & $21 \mathrm{~g}$ & $21 \mathrm{~g}$ & $21 \mathrm{~g}$ & $21 \mathrm{~g}$ & $21 \mathrm{~g}$ \\
\hline Food consumption (24 h) & $38 \mathrm{~g}$ & $40 \mathrm{~g}$ & $42 \mathrm{~g}$ & $38 \mathrm{~g}$ & $44 \mathrm{~g}$ \\
\hline Water consumption for $24 \mathrm{~h}$ & $22 \mathrm{ml}$ & $23 \mathrm{ml}$ & $20 \mathrm{ml}$ & $22 \mathrm{ml}$ & $22 \mathrm{ml}$ \\
\hline Body temperature & Normal & Normal & Normal & Normal & Normal \\
\hline Visible abnormalities & NIL & NIL & NIL & $\mathrm{NIL}$ & NIL \\
\hline Rate of respiration & Normal & Normal & Normal & Normal & Normal \\
\hline Drowsiness & Not observed & Not observed & Not observed & Not observed & Not observed \\
\hline Lethargy & Not observed & Not observed & Not observed & Not observed & Not observed \\
\hline Stool colour & Dark Black & Dark Black & Dark Black & Dark Black & Dark Black \\
\hline Urination & Normal & Normal & Normal & Normal & Normal \\
\hline Diarrhoea & NIL & NIL & NIL & NIL & NIL \\
\hline Mucoid stool & NIL & NIL & NIL & NIL & $\mathrm{NIL}$ \\
\hline Eye colour / Pigmentation & Normal & Normal & Normal & Normal & Normal \\
\hline Skin colour & Normal & Normal & Normal & Normal & Normal \\
\hline Rashes & Not seen & Not seen & Not seen & Not seen & Not seen \\
\hline Mobility & 34 mins. & 35 mins & 32 mins. & 35 mins. & 33 mins. \\
\hline Paw jumping & NIL & NIL & NIL & $\mathrm{NIL}$ & $\mathrm{NIL}$ \\
\hline Paw licking & Not seen & Not seen & Not seen & Not seen & Not seen \\
\hline Paw biting & Not observed & Not observed & Not observed & Not observed & Not observed \\
\hline Mortality & Alive & Alive & Alive & Alive & Alive \\
\hline
\end{tabular}

urinations, food and water intake, respiration, convulsion, tremor, constipations and changes in colors of eye and skin, at different time interval from $30 \mathrm{~min}, 1,2,4$, to $6 \mathrm{~h}$ after dosing and twice a day thereafter for the 14-day experimental period. The body weights of all animals were recorded at initially to dosing and on days $1,3,5,7$, and 14 once dosing by using a digital balance (Sartorious Co., Germany) [39].

\section{Sub-acute toxicity study}

The OECD guideline (OECD 407) was followed for evaluation of acute toxicity study. Female swiss albino mice (4-week old) (18-22 g) were divided into five groups, each comprising 5 animals. The first group present as a normal control group received normal saline (NCX), while 2nd, 3rd, 4th and 5th was considered as toxic groups received $\mathrm{PHC}$ (dissolved in distilled water) orally at dose of $250 \mathrm{mg} / \mathrm{kg} /$ p.o. (TX1), $500 \mathrm{mg} /$ kg/p.o. (TX2), $1000 \mathrm{mg} / \mathrm{kg} /$ p.o. (TX3) and $2000 \mathrm{mg} / \mathrm{kg} /$ p.o. (TX4) daily for 28 day. Control group was fed with only normal food and water. Animals were weighed on alternate days and the weight was noted down [40]. On 29th day the animals were anesthetized with thiopental sodium and blood was collected through retro-orbital

Table 3 Effect of polyherbal combination (PHC) on average organ weight (g) of mice

\begin{tabular}{|c|c|c|c|c|c|}
\hline \multirow[t]{3}{*}{ Organ } & \multicolumn{5}{|c|}{ Average organ weight (gm) } \\
\hline & Distilled water & $250 \mathrm{mg} / \mathrm{kg} /$ day & $500 \mathrm{mg} / \mathrm{kg} / \mathrm{day}$ & $1000 \mathrm{mg} / \mathrm{kg} / \mathrm{day}$ & $2000 \mathrm{mg} / \mathrm{kg} /$ day \\
\hline & $\mathrm{NCX}$ & TX1 & TX2 & TX3 & TX4 \\
\hline Brain & $0.398 \pm 0.046$ & $0.393 \pm 0.039$ & $0.397 \pm 0.400$ & $0.4 \pm 0.045$ & $0.392 \pm 0.046$ \\
\hline Heart & $0.186 \pm 0.007$ & $0.184 \pm 0.002$ & $0.188 \pm 0.012$ & $0.188 \pm 0.009$ & $0.186 \pm 0.007$ \\
\hline Kidney $(L+R)$ & $0.265 \pm 0.009$ & $0.265 \pm 0.010$ & $0.31 \pm 0.065$ & $0.268 \pm 0.013$ & $0.267 \pm 0.013$ \\
\hline Liver & $1.278 \pm 0.031$ & $1.282 \pm 0.032$ & $1.283 \pm 0.035$ & $1.28 \pm 0.035$ & $1.284 \pm 0.033$ \\
\hline Lung & $0.275 \pm 0.010$ & $0.281 \pm 0.012$ & $0.281 \pm 0.003$ & $0.276 \pm 0.010$ & $0.276 \pm 0.009$ \\
\hline Weight of animal on the day of sacrifice & $21.273 \pm 1.172$ & $21.69 \pm 0.378$ & $22.067 \pm 0.943$ & $22.15 \pm 1.089$ & $21.25 \pm 1.110$ \\
\hline
\end{tabular}

The values were depicted as means \pm SD for 5 mice per group. Statistically significant differences between groups were measured using one-way ANOVA with nonparametric paired t- test. The values in different treated groups were found to be non-significant $(p>0.05)$ when compared with normal control group (NCX) 
Table 4 Effect of oral administration of polyherbal combination ( $\mathrm{PHC}$ ) on relative organ weight (g) of mice

\begin{tabular}{|c|c|c|c|c|c|}
\hline \multirow[t]{3}{*}{ Organ } & \multicolumn{5}{|c|}{ Relative organ weight (gm) } \\
\hline & Distilled water & $250 \mathrm{mg} / \mathrm{kg} /$ day & $500 \mathrm{mg} / \mathrm{kg} /$ day & 1000 mg/kg/day & $2000 \mathrm{mg} / \mathrm{kg} / \mathrm{day}$ \\
\hline & $\mathrm{NCX}$ & TX1 & TX2 & TX3 & TX4 \\
\hline Brain & $1.874 \pm 0.220$ & $1.816 \pm 0.208$ & $1.795 \pm 0.108$ & $1.804 \pm 0.161$ & $1.842 \pm 0.142$ \\
\hline Heart & $0.875 \pm 0.040$ & $0.85 \pm 0.005$ & $0.851 \pm 0.068$ & $0.851 \pm 0.078$ & $0.879 \pm 0.069$ \\
\hline Kidney $(L+R)$ & $1.249 \pm 0.075$ & $1.222 \pm 0.046$ & $1.4 \pm 0.253$ & $1.214 \pm 0.113$ & $1.26 \pm 0.117$ \\
\hline Liver & $6.024 \pm 0.431$ & $5.91 \pm 0.074$ & $5.822 \pm 0.348$ & $5.793 \pm 0.433$ & $6.059 \pm 0.470$ \\
\hline Lung & $1.293 \pm 0.068$ & $1.294 \pm 0.043$ & $1.274 \pm 0.063$ & $1.249 \pm 0.098$ & $1.303 \pm 0.092$ \\
\hline
\end{tabular}

The values were depicted as means \pm SD for 5 mice per group. Statistically significant differences between groups were measured using one-way ANOVA with nonparametric paired t-test. The values in different treated groups were found to be non-significant $(p>0.05)$ when compared to normal control group (NCX)

plexus and tail vein in 2 tubes and analyzed for hematological parameters and biochemical parameters. Later animals were sacrificed and visceral organ were excised out carefully, immediately organs were washed by using ice-cold saline $(0.9 \% \mathrm{NaCl})$ along with $20 \mathrm{mM}$ EDTA to remove the blood, dried with tissue paper, weighed and were stored in $10 \%$ formalin solution, the stored organs were used for histopathological examination. Mortality in each group was recorded throughout the course of the 28-day oral administration of the PHC.

\section{Body weight and relative organ weight}

The body weight was determined on each alternate day throughout the subacute toxicity study by using a digital balance. After the 28 days the animals were sacrificed and all organs were collected, the blood was removed from each organ such as heart, brain, liver, kidney, pancreas, intestine and lungs and weighed each organ on digital balance and the relative organ weight was calculated by formula mentioned below [41].

$$
\frac{\text { Weight of Organ }}{\text { Weight of animal on the day of sacrifice }} \times 100
$$

\section{Hematological analysis}

The following hematological parameters were evaluated from the collected blood sample: Red blood corpuscle (RBC) count, hemoglobin (HB), hematocrit (HCT), platelet (PLT) count, white blood corpuscle (WBC) count, DLC, PCV, MCV, MCH and MCHC [42, 43].

\begin{tabular}{|c|c|c|c|c|c|}
\hline \multirow[t]{3}{*}{ Organ } & \multicolumn{5}{|c|}{ Hematological parameter } \\
\hline & Distilled water & $250 \mathrm{mg} / \mathrm{kg} /$ day & $500 \mathrm{mg} / \mathrm{kg} /$ day & $1000 \mathrm{mg} / \mathrm{kg} / \mathrm{day}$ & $2000 \mathrm{mg} / \mathrm{kg} /$ day \\
\hline & NCX & TX1 & TX2 & TX3 & TX4 \\
\hline Neutrophils (\%) & $17.597 \pm 0.272$ & $17.637 \pm 0.631$ & $17.703 \pm 0.666$ & $17.693 \pm 0.836$ & $18.333 \pm 0.917$ \\
\hline Lymphocyte (\%) & $78.267 \pm 0.074$ & $78.313 \pm 0.264$ & $78.357 \pm 0.329$ & $78.39 \pm 0.349$ & $78.34 \pm 0.161$ \\
\hline Monocyte (\%) & $2.673 \pm 0.245$ & $2.66 \pm 0.510$ & $2.597 \pm 0.405$ & $2.763 \pm 0.636$ & $2.657 \pm 0.448$ \\
\hline Reticulocyte (\%) & $1.5 \pm 0.282$ & $1.517 \pm 0.168$ & $1.59 \pm 0.176$ & $1.553 \pm 0.222$ & $1.537 \pm 0.318$ \\
\hline $\mathrm{RBC}\left(10^{6} / \mu \mathrm{L}\right)$ & $7.567 \pm 0.254$ & $7.583 \pm 0.105$ & $7.623 \pm 0.136$ & $7.427 \pm 0.212$ & $7.607 \pm 0.240$ \\
\hline WBC $\left(10^{3} / \mu \mathrm{L}\right)$ & $8.8 \pm 0.819$ & $8.823 \pm 1.043$ & $8.867 \pm 1.076$ & $8.883 \pm 0.982$ & $8.86 \pm 1.223$ \\
\hline Platelet $\left(10^{3} / \mu \mathrm{L}\right)$ & $1048.667 \pm 24.338$ & $1055.667 \pm 54.077$ & $1059.667 \pm 61.158$ & $1064.667 \pm 66.109$ & $1057.667 \pm 53.116$ \\
\hline $\mathrm{PCV}(\mathrm{L} / \mathrm{L})$ & $43.3 \pm 0.248$ & $43.337 \pm 0.409$ & $43.44 \pm 0.447$ & $43.39 \pm 0.501$ & $43.37 \pm 0.244$ \\
\hline MCV (L/L) & $58.313 \pm 0.333$ & $58.353 \pm 0.528$ & $58.393 \pm 0.585$ & $58.417 \pm 0.625$ & $58.367 \pm 0.388$ \\
\hline $\mathrm{MCH}(\mathrm{pg})$ & $20.047 \pm 0.174$ & $20.263 \pm 0.289$ & $20.163 \pm 0.145$ & $20.147 \pm 0.261$ & $20.277 \pm 0.460$ \\
\hline $\mathrm{MCHC}(g / \mu l)$ & 32.4430 .331 & $32.483 \pm 0.542$ & $32.677 \pm 0.746$ & $32.52 \pm 0.609$ & $32.507 \pm 0.589$ \\
\hline Eosinophil's (\%) & $1.613 \pm 0.320$ & $1.627 \pm 0.368$ & $1.56 \pm 0.236$ & $1.677 \pm 0.485$ & $1.65 \pm 0.197$ \\
\hline Basophils (\%) & $0.513 \pm 0.025$ & $0.553 \pm 0.100$ & $0.583 \pm 0.035$ & $0.583 \pm 0.067$ & $0.573 \pm 0.064$ \\
\hline Hematocrit (\%) & $41.39 \pm 0.383$ & $41.42 \pm 0.171$ & $41.507 \pm 0.264$ & $41.473 \pm 0.251$ & $41.44 \pm 0.128$ \\
\hline Hemoglobin (\%) & $14.467 \pm 0.352$ & $14.553 \pm 0.439$ & $14.613 \pm 0.593$ & $14.547 \pm 0.705$ & $14.587 \pm 0.292$ \\
\hline
\end{tabular}

Table 5 Effect of polyherbal combination (PHC) on hematological parameter

The values were depicted as means \pm SD for 5 mice per group. Statistically significant differences between groups were measured using one-way ANOVA with nonparametric paired $t$ - test. The values in different treated groups were found to be non-significant $(p>0.05)$ when compared to normal control group (NCX) 
Table 6 Effect of polyherbal combination (PHC) on biochemical parameter

\begin{tabular}{|c|c|c|c|c|c|}
\hline \multirow[t]{3}{*}{ Organ } & \multicolumn{5}{|c|}{ Biochemical parameter } \\
\hline & Distilled water & $250 \mathrm{mg} / \mathrm{kg} / \mathrm{day}$ & $500 \mathrm{mg} / \mathrm{kg} / \mathrm{day}$ & 1000 mg/kg/day & $2000 \mathrm{mg} / \mathrm{kg} / \mathrm{day}$ \\
\hline & NCX & TX1 & TX2 & TX3 & TX4 \\
\hline SGOT or AST (IU/L) & $74.64 \pm 3.821$ & $75.207 \pm 3.490$ & $75.097 \pm 2.531$ & $75.583 \pm 1.765$ & $74.82 \pm 3.810$ \\
\hline SGPT or ALT (IU/L) & $43.987 \pm 3.185$ & $44.39 \pm 2.811$ & $44.46 \pm 3.438$ & $45.27 \pm 3.222$ & $43.707 \pm 1.262$ \\
\hline GGT (IU/L) & $0.417 \pm 0.035$ & $0.423 \pm 0.040$ & $0.427 \pm 0.035^{* * *}$ & $0.433 \pm 0.021$ & $0.417 \pm 0.038$ \\
\hline ALP (IU/L) & $564.26 \pm 24.783$ & $565.32 \pm 24.716$ & $565.153 \pm 23.846$ & $565.953 \pm 24.871$ & $571.453 \pm 28.153$ \\
\hline
\end{tabular}

The values were depicted as means \pm SD for 5 mice per group. Statistically significant differences between groups were measured using one-way ANOVA with nonparametric paired t- test. Where ${ }^{* * *} p<0.001$, highly significant; when the values was compared with normal control group (NCX)

The estimation was done by the use of autoanalyzer (Icount3 TS, Iris Healthcare, Mumbai).

\section{Biochemical parameters}

Serum samples were analyzed for the following parameters: Serum Glutamic Pyruvate transaminase (SGPT) or Alanine Transaminase (ALT), Serum Glutamic Oxaloacetic Transaminase (SGOT) or Aspartate aminotransferase (AST) was estimated by procedure mentioned in commercially available diagnostic kit (Coral Clinical Systems, A unit of Tulip Diagnostics (P) Ltd. Goa), Serum Alkaline Phosphatase (ALP) [44] and Gamma-glutamyl transferase (GGT) [45].

\section{Protein estimation}

The serum protein estimation was performed to examine change in protein level. Following parameters were evaluated. Total protein (TP) [46], Albumin (Alb) [47], Globulin (Glb). Serum globulin was calculated by subtracting serum albumin from serum total proteins, followed by estimation of Albumin:Globulin ratio (A/G ratio).

\section{Kidney function test}

Kidney function test is performed to observe the variation in kidney markers and electrolyte levels. Following parameters were estimated. Serum total bilirubin was estimated by the Jendrassik-Grof method [48] Blood Urea Nitrogen (BUN) was estimated by the Berthelot-Searcy method [49], while serum creatinine was estimated by the modified Jaffe method [50].

Blood Glucose, Urea and Uric acid was estimated by using commercially available diagnostic kit respectively (Agappe Diagnostics Ltd., India) (Reckon Diagnostics Pvt. Ltd) respectively while sodium was determined by using automatic electrolyte analyser (Elyte-i5, Tulip Diagnostics (P) Ltd., India).

\section{Lipid profile}

Total cholesterol (TChol), triglyceride (TG), low density lipoprotein (LDL), high density lipoprotein (HDL) and very low-density lipoprotein (VLDL) were analysed. The estimation was done by using commercially available diagnostic kits using semi-automatic analyser (BC300, Contec, China).

\section{Antioxidant enzyme estimation}

Erythrocytes and their membranes were secluded from experimental and control groups according to the protocol of Dodge et al. with minor modifications [51].

The following antioxidant enzymes were estimates from the hemolysate such as GSH [52], Catalase (CAT) [53], Superoxide dismutase (SOD) [54], Glutathione peroxidase (GPX) activity was estimated with slight modification [55].

\section{Histopathological assessment}

On 28th day before collecting blood samples again weighed the animals and sacrificed after anaesthetizing

Table 7 Effect of polyherbal combination (PHC) on protein content

\begin{tabular}{|c|c|c|c|c|c|}
\hline \multirow[t]{3}{*}{ Organ } & \multicolumn{5}{|l|}{ Protein content } \\
\hline & Distilled water & $250 \mathrm{mg} / \mathrm{kg} / \mathrm{day}$ & $500 \mathrm{mg} / \mathrm{kg} / \mathrm{day}$ & $1000 \mathrm{mg} / \mathrm{kg} / \mathrm{day}$ & $2000 \mathrm{mg} / \mathrm{kg} / \mathrm{day}$ \\
\hline & NCX & TX1 & TX2 & TX3 & TX4 \\
\hline Total Protein (g/dL) & $6.333 \pm 0.355$ & $6.42 \pm 0.233$ & $6.527 \pm 0.172$ & $6.643 \pm 0.102$ & $6.28 \pm 0.384$ \\
\hline Globulin (g/dL) & $2.813 \pm 0.116$ & $2.823 \pm 0.136$ & $2.843 \pm 0.081$ & $2.867 \pm 0.067$ & $2.8 \pm 0.095$ \\
\hline Albumin (g/dL) & $2.573 \pm 0.178$ & $2.593 \pm 0.090$ & $2.593 \pm 0.090$ & $2.653 \pm 0.136$ & $2.593 \pm 0.144$ \\
\hline A/G (ratio) & $0.917 \pm 0.088$ & $0.919 \pm 0.034$ & $0.913 \pm 0.051$ & $0.926 \pm 0.057$ & $0.928 \pm 0.076$ \\
\hline
\end{tabular}

The values were depicted as means \pm SD for 5 mice per group. Statistically significant differences between groups were measured using one-way ANOVA with nonparametric paired $t$ - test. The values in different treated groups were found to be non-significant $(p>0.05)$ when compared to normal control group (NCX) 
Table 8 Effect of polyherbal combination (PHC) on kidney function test

\begin{tabular}{|c|c|c|c|c|c|}
\hline \multirow[t]{3}{*}{ Organ } & \multicolumn{5}{|c|}{ Kidney function test } \\
\hline & Distilled water & $250 \mathrm{mg} / \mathrm{kg} /$ day & $500 \mathrm{mg} / \mathrm{kg} /$ day & $1000 \mathrm{mg} / \mathrm{kg} / \mathrm{day}$ & $2000 \mathrm{mg} / \mathrm{kg} / \mathrm{day}$ \\
\hline & NCX & TX1 & TX2 & TX3 & TX4 \\
\hline Total Bilirubin (mg/dL) & $0.513 \pm 0.031$ & $0.513 \pm 0.031$ & $0.543 \pm 0.050$ & $0.527 \pm 0.025$ & $0.513 \pm 0.038$ \\
\hline Glucose (mg/dL) & $133.667 \pm 6.807$ & $135 \pm 5.240$ & $135.687 \pm 6.846^{* * *}$ & $135.303 \pm 4.559$ & $134.31 \pm 3.822$ \\
\hline BUN (mg/dL) & $16.53 \pm 0.407$ & $16.553 \pm 0.323$ & $16.703 \pm 0.355$ & $16.633 \pm 0.224$ & $16.31 \pm 0.375$ \\
\hline Creatinine $(\mathrm{mg} / \mathrm{dL})$ & $0.44 \pm 0.111$ & $0.463 \pm 0.105$ & $0.470 \pm 0.135$ & $0.477 \pm 0.106^{*}$ & $0.437 \pm 0.129$ \\
\hline Sodium (mmol/L) & $134.51 \pm 1.43$ & $133.63 \pm 0.88$ & $135.82 \pm 1.05$ & $134.12 \pm 1.53$ & $136.47 \pm 1.83$ \\
\hline Urea (mg/dL) & $47.84 \pm 2.44$ & $46.91 \pm 1.69$ & $46.07 \pm 2.19$ & $47.99 \pm 1.89$ & $48.53 \pm 2.59$ \\
\hline Uric acid (mg/dL) & $2.04 \pm 0.41$ & $2.33 \pm 0.52$ & $2.67 \pm 0.69$ & $2.61 \pm 0.24$ & $2.83 \pm 0.84$ \\
\hline
\end{tabular}

The values were depicted as means \pm SD for 5 mice per group. Statistically significant differences between groups were measured using one-way ANOVA with nonparametric paired t- test

Where ${ }^{* * *} p<0.001$, highly significant; ${ }^{*} p<0.05$, significant when the values was compared with normal control group (NCX)

the animals with thiopental sodium, brain, lungs, heart, stomach, intestine, liver, spleen and kidney were dissected out washed with normal saline and weighed. The organs were kept in $10 \%$ formalin solutions. The total gross examinations of the organs were performed and visible superficial, morphological and anatomical abnormalities were recorded. Later the organs were embedded in paraffin wax, sliced into $4 \mu \mathrm{m}$ section and further stained by using Hematoxylin and Eosin. Under light microscope, the pictomicrograph was obtained for histopathological evaluation in this study (Mshot MD30-B). The analysis was performed by experienced pathologist, unaware of different treatment group as coding of each organ was done.

\section{Statistical analysis}

The results were signified as means \pm standard deviation (SD). The quantitative statistical analysis was performed by using the statistical analysis software GraphPad prism 6.0. The differences between the treatment group and normal control groups was identified by applying analysis of variance (one-way ANOVA) followed by Dunnet test, the nonparametric paired t-test was performed to compare a couple of variables and obtain the significance level. Significance was measured at values of $p<0.05$. A value of $p>0.05$ was considered nonsignificant.

\section{Results}

\section{Acute toxicity study}

In acute toxicity testing, all the observations were completed very precisely for the development of any toxic marks at different time frame of $0,30 \mathrm{~min}, 1,2,4,6,8$, $12 \mathrm{~h}$. and then once daily for 14 days. No toxic signs were observed in any clinical, behavioral parameters at any treated dose throughout acute toxicity study when it was compared with normal control group. So, it was assumed that the $\mathrm{LD}_{50}$ of the PHC is larger than $2000 \mathrm{mg} /$ $\mathrm{kg} /$ day body weight (Table 2 ).

\section{Sub-acute toxicity study}

The sub-acute study was conducted for 4 weeks $(28$ days) with four completely different doses; $250 \mathrm{mg} / \mathrm{kg} /$ day (TX1), $500 \mathrm{mg} / \mathrm{kg} /$ day (TX2), $1000 \mathrm{mg} / \mathrm{kg} /$ day (TX3), $2000 \mathrm{mg} / \mathrm{kg}$ day (TX4) and one group treated as normal control group (NC) according to OECD guideline 425 . The parameters estimated were body weight and average and relative organ weight, hematological

Table 9 Effect of polyherbal combination (PHC) on lipid profile

\begin{tabular}{|c|c|c|c|c|c|}
\hline \multirow[t]{3}{*}{ Organ } & \multicolumn{5}{|l|}{ Lipid profile } \\
\hline & Distilled water & $250 \mathrm{mg} / \mathrm{kg} / \mathrm{day}$ & $500 \mathrm{mg} / \mathrm{kg} /$ day & $1000 \mathrm{mg} / \mathrm{kg} / \mathrm{day}$ & $2000 \mathrm{mg} / \mathrm{kg} / \mathrm{day}$ \\
\hline & NCX & TX1 & TX2 & TX3 & TX4 \\
\hline $\mathrm{HDL}(\mathrm{mg} / \mathrm{dL})$ & $50.137 \pm 3.255$ & $51.379 \pm 1.559$ & $51.663 \pm 6.215$ & $53.043 \pm 3.978$ & $51.093 \pm 8.837$ \\
\hline $\mathrm{LDL}(\mathrm{mg} / \mathrm{dL})$ & $35.94 \pm 2.446$ & $36.587 \pm 2.114$ & $36.973 \pm 2.274$ & $37.097 \pm 2.339$ & $35.807 \pm 1.709$ \\
\hline VLDL (mg/dL) & $54.587 \pm 2.978$ & $53.557 \pm 2.864$ & $53.115 \pm 6.589$ & $52.987 \pm 3.857$ & $52.281 \pm 3.852$ \\
\hline Total Cholesterol (mg/dL) & $87.94 \pm 6.157$ & $86.697 \pm 5.333$ & $86.713 \pm 7.561$ & $85.397 \pm 11.021$ & $86.767 \pm 9.941$ \\
\hline Triglyceride (mg/dL) & $95.727 \pm 3.422$ & $95.203 \pm 3.487$ & $95.043 \pm 3.481$ & $94.644 \pm 2.307$ & $94.821 \pm 1.257$ \\
\hline
\end{tabular}

The all values represent the means \pm SD for 5 mice per group. The values were depicted as means \pm SD for 5 mice per group. Statistically significant differences between groups were measured using one-way ANOVA with nonparametric paired t- test. The values in different treated groups were found to be non-significant $(p>0.05)$ when compared with normal control group (NCX) 
Table 10 Effect of polyherbal combination (PHC) on antioxidant enzymes

\begin{tabular}{|c|c|c|c|c|c|}
\hline \multirow[t]{3}{*}{ Organ } & \multicolumn{5}{|c|}{ Antioxidant enzyme } \\
\hline & Distilled water & $250 \mathrm{mg} / \mathrm{kg} / \mathrm{day}$ & $500 \mathrm{mg} / \mathrm{kg} /$ day & $1000 \mathrm{mg} / \mathrm{kg} / \mathrm{day}$ & $2000 \mathrm{mg} / \mathrm{kg} /$ day \\
\hline & NCX & TX1 & TX2 & TX3 & TX4 \\
\hline $\mathrm{SOD}(\mathrm{U} / \mathrm{gHb})$ & $348.08 \pm 21.33$ & $354.52 \pm 27.95$ & $342.33 \pm 22.51$ & $355.07 \pm 26.83$ & $359.38 \pm 29.10$ \\
\hline $\mathrm{GPx}(\mathrm{U} / \mathrm{gHb})$ & $33.71 \pm 1.09$ & $35.41 \pm 1.62$ & $34.92 \pm 0.98$ & $35.27 \pm 0.32$ & $36.71 \pm 1.24$ \\
\hline $\mathrm{GSH}(\mathrm{mg} / \mathrm{dl})$ & $4.19 \pm 0.03$ & $4.33 \pm 0.04$ & $4.17 \pm 0.03$ & $7.73 \pm 0.32^{* *}$ & $4.24 \pm 0.03$ \\
\hline CATALASE $(\mathrm{U} / \mathrm{gHb})$ & $64.51 \pm 2.88$ & $65.42 \pm 2.81$ & $65.05 \pm 2.74$ & $66.45 \pm 2.72$ & $71.36 \pm 3.17$ \\
\hline
\end{tabular}

The values were depicted as means \pm SD for 5 mice per group. Statistically significant differences between groups were measured using one-way ANOVA with nonparametric paired t- test. Where ${ }^{* *} p<0.01$, very significant when the values was compared with normal control group (NCX)

parameters (WBCs, RBCs, PLT, Hb, MCH, MCV, and $\mathrm{MCHC}$ ), liver function parameters (Bilirubin, ALT, AST), renal function profile (blood urea, creatinine, and uric acid), protein and lipid profile estimation (triglycerides, cholesterol, HDL, VLDL). No clinical toxicity symptoms were determined at any treated dose within the different PHC treated group when compared to the normal control group (NCX).

\section{Effect of PHC on average and relative organ weight}

There was no significant distinction in average organs weight and relative organs weight between normal control (NCX) and PHC treated group at selected dose of PHC
$(250 \mathrm{mg} / \mathrm{kg} /$ day, $\quad 500 \mathrm{mg} / \mathrm{kg} /$ day, $1000 \mathrm{mg} / \mathrm{kg} /$ day, 2000 $\mathrm{mg} / \mathrm{kg}$ day). The result of PHC on average and relative organ weights to body weight is shown in Tables 3 and 4 respectively. There was no significant distinction within the changes of each organ weight. The results discovered that, the essential organs have no adverse effect throughout the treatment by PHC. The average and relative organ weight of PHC treated and control groups (NCX) shown statistically non-significant differences $(P>0.05)$.

\section{Effect of PHC on hematological parameters}

The results of all parameters of hematological tests are compiled in Table 5. No toxicologically significant

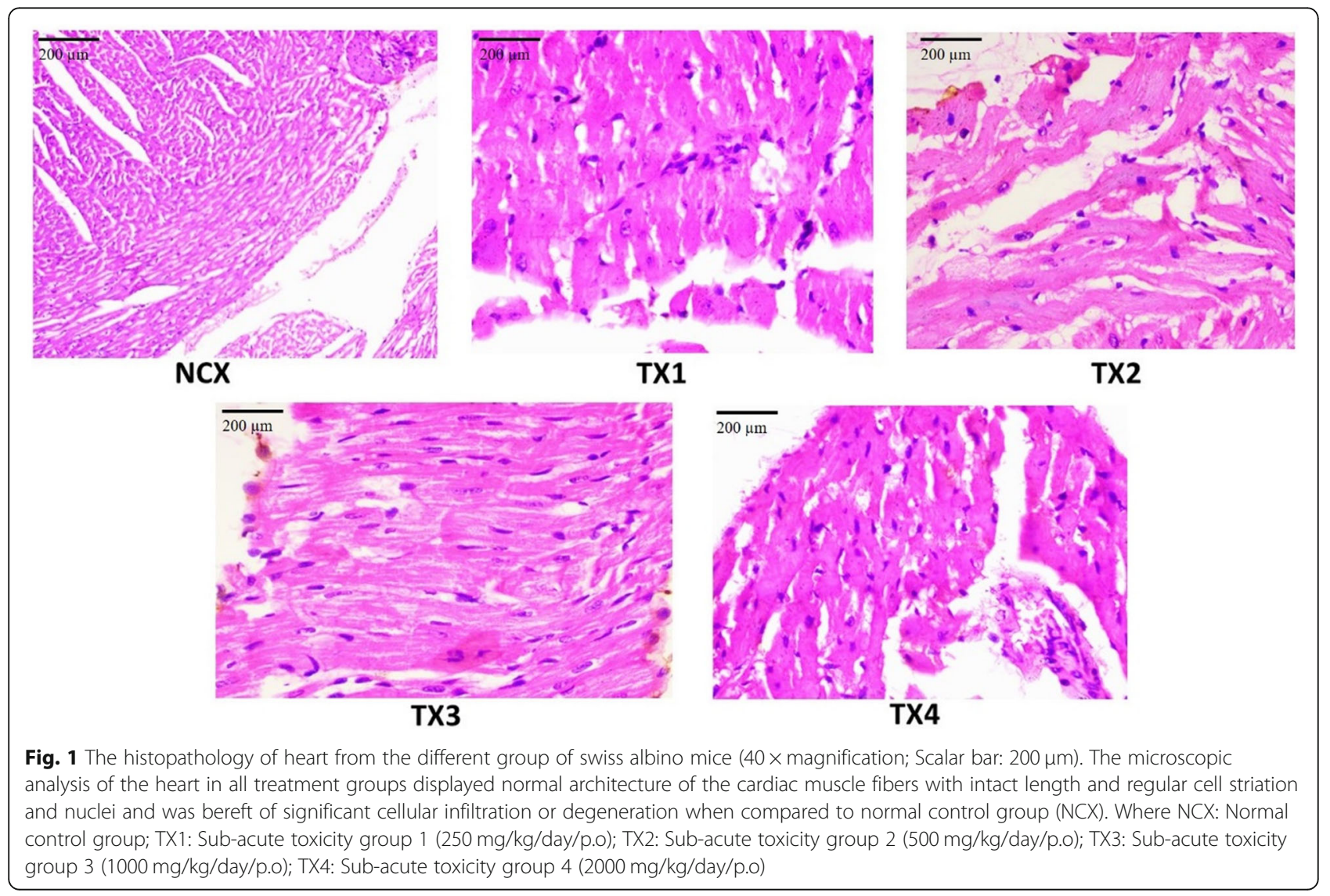


variations $(P>0.05)$ between different treated animals with the PHC and normal control (NCX) were found.

\section{Effect of PHC on biochemical parameter}

Oral administration of PHC at given dose of $250 \mathrm{mg} / \mathrm{kg} /$ day, $500 \mathrm{mg} / \mathrm{kg} /$ day, $1000 \mathrm{mg} / \mathrm{kg} /$ day, $2000 \mathrm{mg} / \mathrm{kg} /$ day, there was no significant change in AST, ALT, ALP level of TX1, TX2, TX3 and TX4 group respectively when compared to Normal control Group (NC). However, In TX2 group, the level of GGT displayed highly significant increase $(p<0.001)$ while no significant changes in level of GGT was observed in TX1, TX3 and TX4 when compared to normal control Group (NCX) (Table 6).

\section{Effect of PHC on protein estimation}

There was no significant change in level of Total protein, Albumin, Globulin and A/G ratio of TX1, TX2, TX3 and TX4 group when compared to normal control Group (NCX) (Table 7).

\section{Effect of PHC on kidney function test}

The Total Bilirubin, BUN, Creatinine, Glucose, Sodium, Urea, Uric acid was estimated and result suggest that there were no significant changes in the kidney function test in different treatment group (TX1, TX2, TX3 and TX4) when compared with normal control group
(NCX). except, in TX2 group, where there was a highly significant increase $(p<0.001)$ in the level of glucose, while in TX3 group, the level of creatinine was increased significantly $(p<0.05)$ when compared with normal control group (NCX) (Table 8).

\section{Effect of PHC on lipid profile}

The results of the various lipid profile tests on the experimentally treated animals with the PHC and control group are compiled in Table 9. Oral administration of $\mathrm{PHC}$ at given dose of $250 \mathrm{mg} / \mathrm{kg} /$ day, $500 \mathrm{mg} / \mathrm{kg} /$ day, $1000 \mathrm{mg} / \mathrm{kg} /$ day, $2000 \mathrm{mg} / \mathrm{kg} /$ day were failed to cause vital changes in serum lipid profile parameters when compared with normal control group (NCX). The level of HDL levels recorded non-significant increase $(p>$ $0.05)$ in all the treated groups when compared to normal control (NCX) whereas total cholesterol, LDL, Triglyceride and VLDL levels recorded non-significant $(p>0.05)$ decrease in all the treated groups compared to normal control group (NCX).

\section{Antioxidant enzyme}

The result suggests that SOD, GPx, CATALASE level in the treated group does not showed any significant differences, while TX3 group showed very significant $(p<0.01)$ differences in the level of GSH, rest other experimental

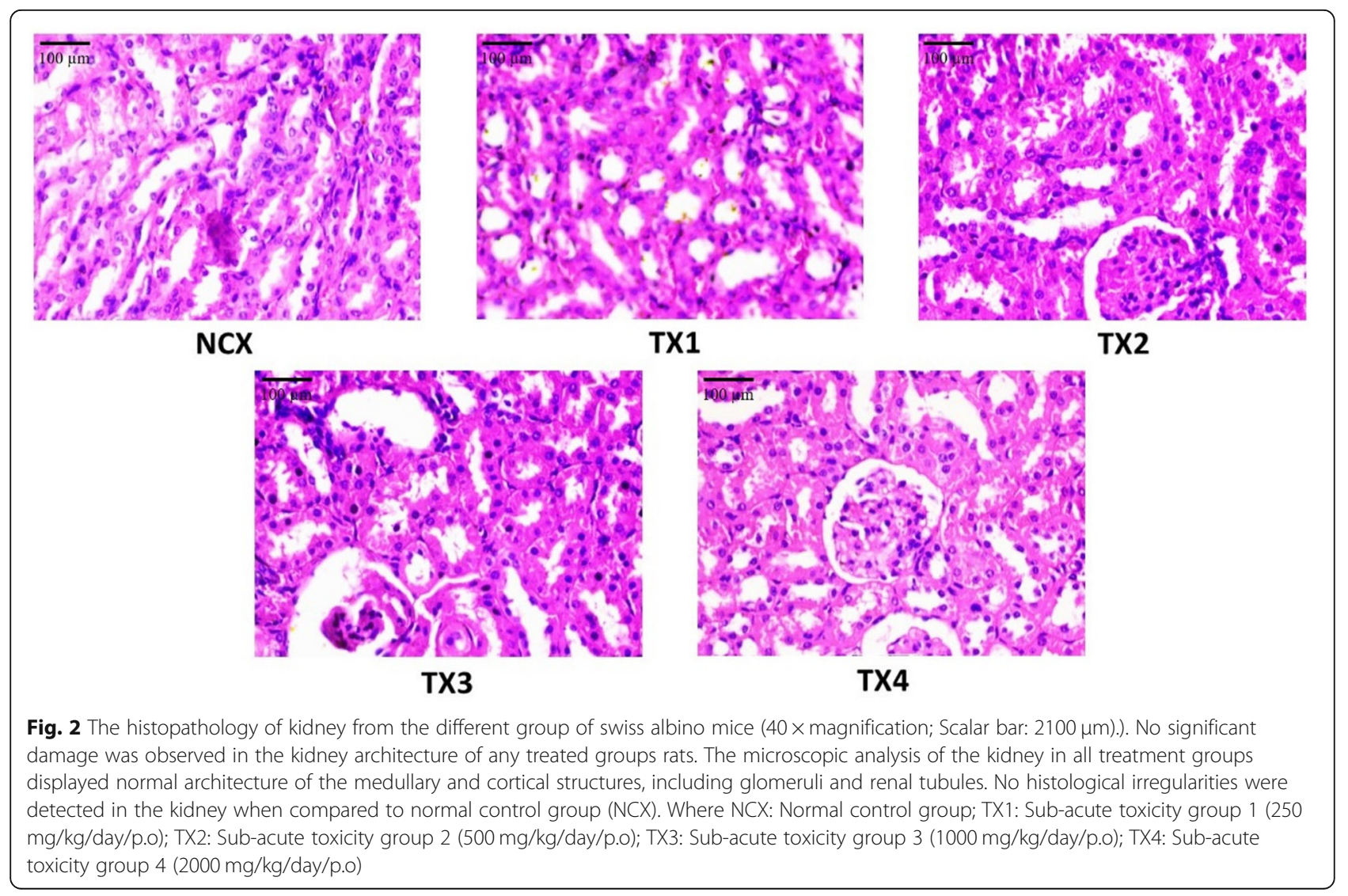




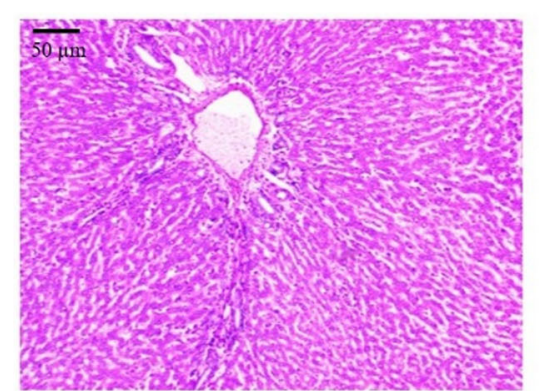

NCX

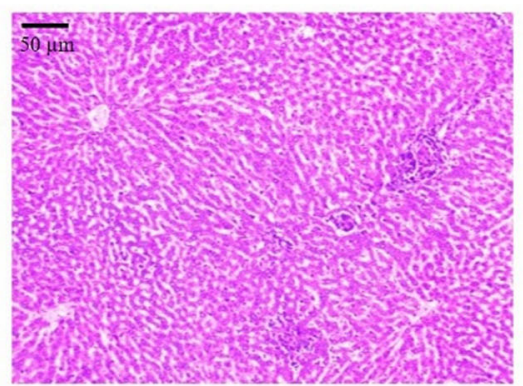

TX1

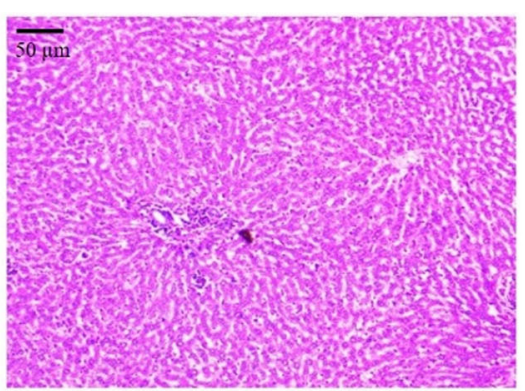

TX2

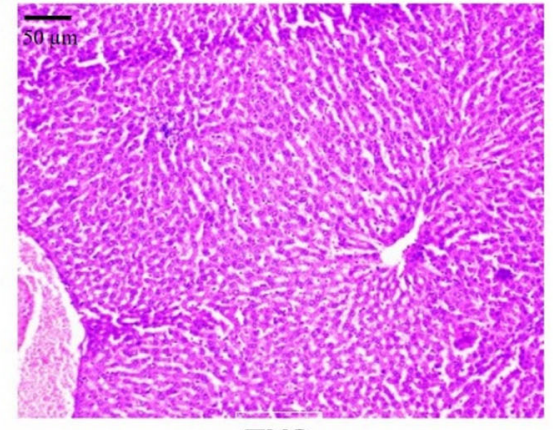

TX3

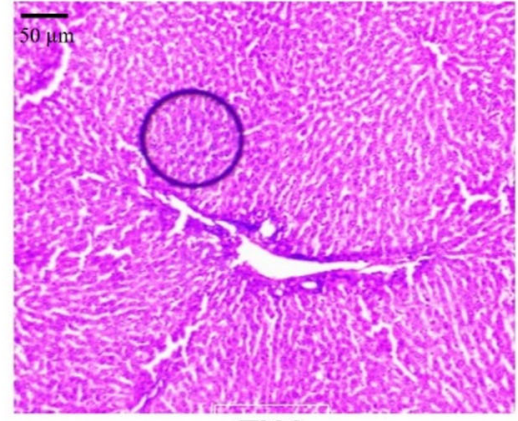

TX4

Fig. 3 The histopathology of Liver from the different group of swiss albino mice ( $40 \times$ magnification; Scalar bar: $50 \mu$ m). The tissue slices displayed intact hepatic parenchyma included of hepatocytes, central vein and portal triad. No significant mixed macro and micro vesicular steatosis, vacuolated hepatocytes or any kind of infiltration was observed in the liver tissue (hepatocytes). Hepatocytes were organized in cords with intact cellular and nucleus borders, when compared to normal control group (NCX). Where NCX: Normal control group; TX1: Sub-acute toxicity group 1 (250 mg/kg/day/p.o); TX2: Sub-acute toxicity group 2 (500 mg/kg/day/p.o); TX3: Sub-acute toxicity group 3 (1000 mg/kg/day/p.o); TX4: Sub-acute toxicity group 4 (2000 mg/kg/day/p.o)

groups of GSH displayed no significant differences when compared to normal control group (Table 10).

\section{Histopathology}

No toxic effects on the histological characteristics of the heart, liver, brain, stomach, intestine, spleen, lung and kidneys of the different dose of PHC treated mice were observed when compared with normal control group (NCX) (Figs. 1, 2, 3, 4, 5, 6, 7 and 8).

The detail studies are as follows:

Heart: The microscopic analysis of the heart in all treatment groups displayed normal architecture of the cardiac muscle fibers with intact length and regular cell striation and nuclei and was bereft of significant cellular infiltration or degeneration.

Kidney: No significant damage was observed in the kidney architecture of any treated groups rats. The microscopic analysis of the kidney in all treatment groups displayed normal architecture of the medullary and cortical structures, including glomeruli and renal tubules. No histological irregularities were detected in the kidney.
Liver: The tissue slices displayed intact hepatic parenchyma included of hepatocytes, central vein and portal triad. No significant mixed macro and micro vesicular steatosis, vacuolated hepatocytes or any kind of infiltration was observed in the liver tissue (hepatocytes). Hepatocytes were organized in cords with intact cellular and nucleus borders.

Lung: All treated groups showed normal lung architecture. No significant damage (such as granulomas, increased alveolar cell wall, Inflammatory cells) was observed in the lung tissue of any treated groups rats. The section showed intact alveolar membrane.

Small Intestine: No significant damage (villi atropy, inflammation, superficial erosion and crypt hyperplasia) was observed in the tissues of small intestine of any treated groups rats. The histology result displays no abnormalities in the microscopic structure of small intestine.

Spleen: No significant damage was observed in the spleen tissue of any treated groups rats. The micropictograph showed the normal white and red pulp areas with no cell breakage in the splenic parenchyma 


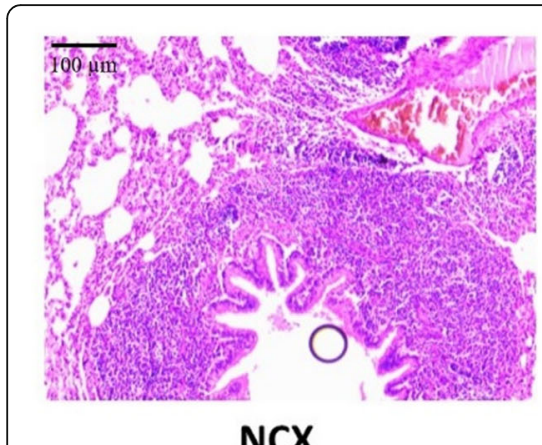

NCX

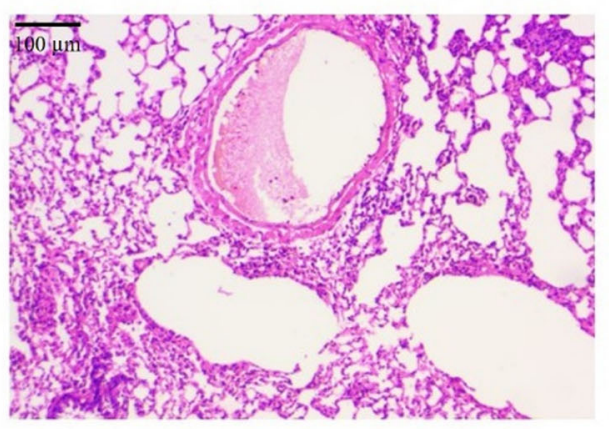

TX3

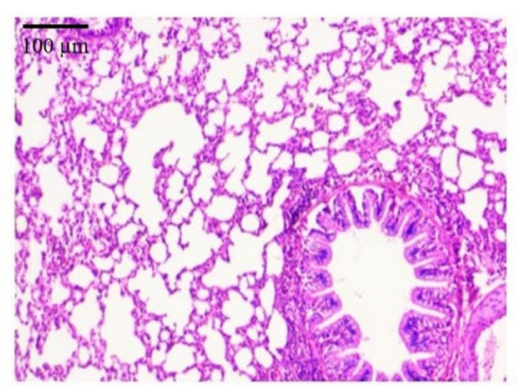

TX1

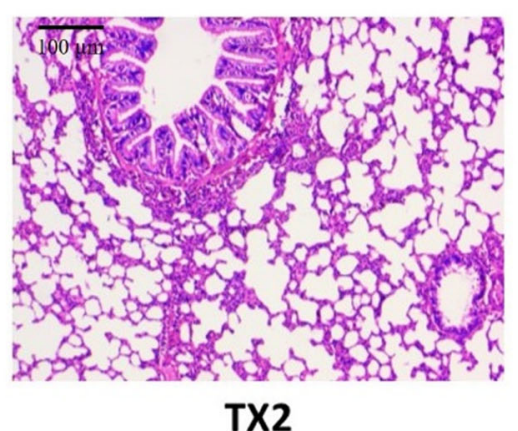

TX2

Fig. 4 The histopathology of lung from the different group of swiss albino mice (40 × magnification; Scalar bar: 100 um). All treated groups showed normal lung architecture. No significant damage (such as Granulomas, increased alveolar cell wall, Inflammatory cells) was observed in the lung tissue of any treated groups rats. The section showed intact alveolar membrane when compared to normal control group (NCX). Where NCX: Normal control group; TX1: Sub-acute toxicity group 1 (250 mg/kg/day/p.o); TX2: Sub-acute toxicity group 2 (500 mg/kg/day/p.o); TX3: Subacute toxicity group 3 (1000 mg/kg/day/p.o); TX4: Sub-acute toxicity group 4 (2000 mg/kg/day/p.o)

Stomach: No significant damage (such as focal necrosis, mucus wall disruption, extensive congestion in mucosa and haemorrhagic bands) was observed in the inner lining of stomach of any treated groups rats. The inner mucus membrane was completely remained intact. Brain: No significant damage (ex. neuronal necrosis, neuronophagia, cellular necrosis, intact glial cells) was observed in the brain cells of any treated groups rats. The architecture of brain cells showed normal architecture.

\section{Discussion}

The World Health Organization's reports suggest that $85 \%$ of the remote population relies on traditional medicine value given the history of medicinal plants used by human beings dates as back as 60,000-year old [56]. The use of medicinal plants in primary health care all over the world, notably in developing countries, is rapidly getting popular as a secure option for treatment and management of lifestyle diseases owing to their surplus, cost effective and natural access. The polyphenolic compounds present in medicinal plants are believed to be safe and are encouraged to be used as over the counter medications [57]. Herbal drugs play a vital role within the management of varied chronic diseases and have received an excellent response by researcher as alternative source to allopathic medication in current times [58].

Polyherbal formulations are widely utilized in developed countries in contrast to allopathic medicines for the treatment of various forms of disorder [59]. Now a days, the herbal products symbolize safety compared to the synthetic allopathic drugs that present fatal adverse effects [60].

To achieve optimal therapeutic aids, the drug if administered in unit dose or once taken for long duration may produce undesirable and toxic effects can't be ignored. The toxicity profile of individual component is available but after doing current literature review, it was found that no systematic evidence on toxicity is available. Consequently, it was decided to perform an acute \& sub-acute toxicity study, this research outcome will not only add merit to its ethnopharmacological outline, but also delivers information on probable health hazards which are likely to rise from single dose or repeated administration of PHC over a fixed period of time [61].

Acute toxicity is well-thought-out to be an initial study which present us the basis for labelling and classification. It also provides preliminary information about the approach of toxic action of a test material and helps in 


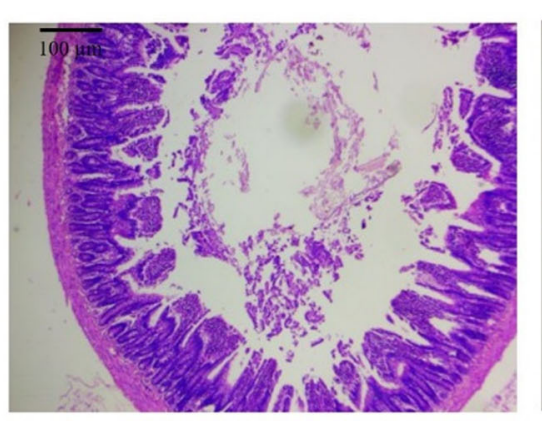

NCX

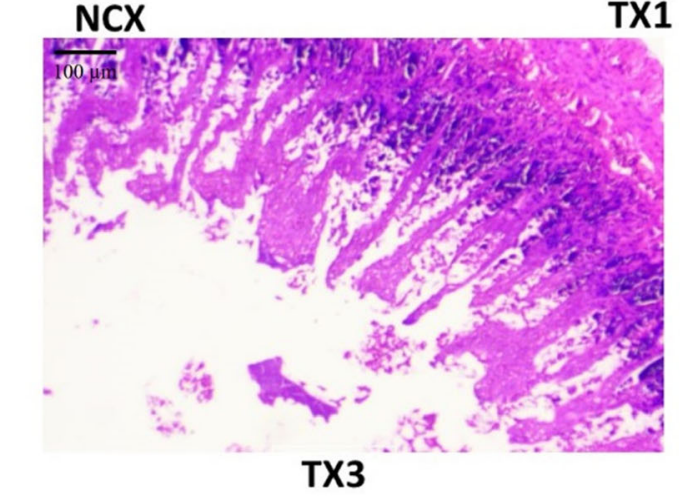

TX3

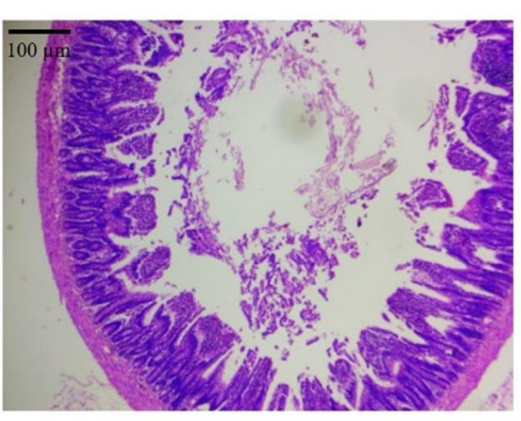

TX1

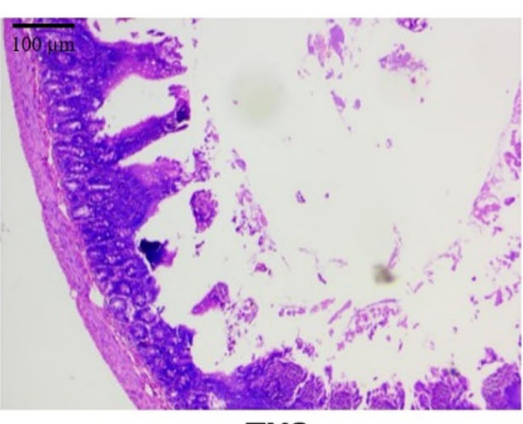

TX2

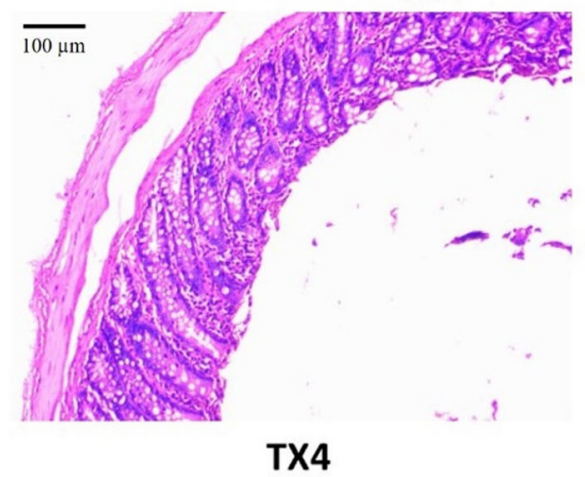

Fig. 5 The histopathology of small intestine from the different group of swiss albino mice (40 × magnification; Scalar bar: $100 \mu \mathrm{m})$. No significant damage (villi atropy, inflammation, superficial erosion and crypt hyperplasia) was observed in the tissues of small intestine of any treated groups rats. The histology result displays no abnormalities in the microscopic structure of small intestine when compared to normal control group (NCX). Where NCX: Normal control group; TX1: Sub-acute toxicity group 1 ( $250 \mathrm{mg} / \mathrm{kg} / \mathrm{day} / \mathrm{p} .0$ ); TX2: Sub-acute toxicity group 2 (500 mg/kg/day/p.o); TX3: Sub-acute toxicity group 3 (1000 mg/kg/day/p.o); TX4: Sub-acute toxicity group 4 (2000 mg/kg/day/p.o)

best estimation of the safe acute doses for humans by which we can frame a dose of a new test compound and help in determination of dose in further animal studies [62].

Following into the herbal plethora of medicinal plants, a polyherbal combination (PHC) of curcumin, quercetin and rutin has been developed for management of diabetic peripheral neuropathy and the present research focuses on the acute and sub-acute toxicity study of the PHC (Curcumin, Quercetin and Rutin) and to identify the range of dose that could be used for further studies on experimental model for diabetic neuropathy. For the acute toxicity study of the PHC, the selected doses $(250 \mathrm{mg} / \mathrm{kg}$, $500 \mathrm{mg} / \mathrm{kg}, 1000 \mathrm{mg} / \mathrm{kg}$ and $2000 \mathrm{mg} / \mathrm{kg}$ body weight) were administered on swiss albino mice at single dose per orally and was continuously observed for $4 \mathrm{~h}$ initially, followed by a total period of $72 \mathrm{~h}$ for any toxic effect after the total treatment period. No major changes were observed in behavior and mortality in all treated groups.

Water, food intake, body weight and toxic signs, if combined together, may specify malaise or conceal toxicity long before explicit signs; if the experimental animal does not feel healthy it will not drink sufficient water/ or eat sufficient amount of food. Hence, food and water intake and, toxicity sign are the marker of overall health. The change in body weight is directly related to intake of food and water along with pathophysiological condition of animals, if there is no toxic effect of test compound, then no significant change in body weight will be observed. Therefore, these parameters are vital to assess the safety profile of the drug during the toxicity study [63]. In the current study, a unit dose administration of Polyherbal combination (PHC) with increasing doses does not produced any serious abnormities, behavioural changes, change in body-weight, change in food and water intake or mortality at all mentioned doses in acute toxicity when compared to normal control group. So, it may perhaps be concluded that oral administration of PHC during Acute toxicity study phase doesn't show undesirable effect on the physiological functions and growth of rats.

Our study demonstrated that there is no significant increase or decrease in the organ weight or relative organ weight in the treated groups when compared to normal control group.

These findings were contemplated toxically irrelevant because the alterations were negligible, further it can be summarised that the administration of PHC at different doses does not cause any toxic effects to the vital organs. 


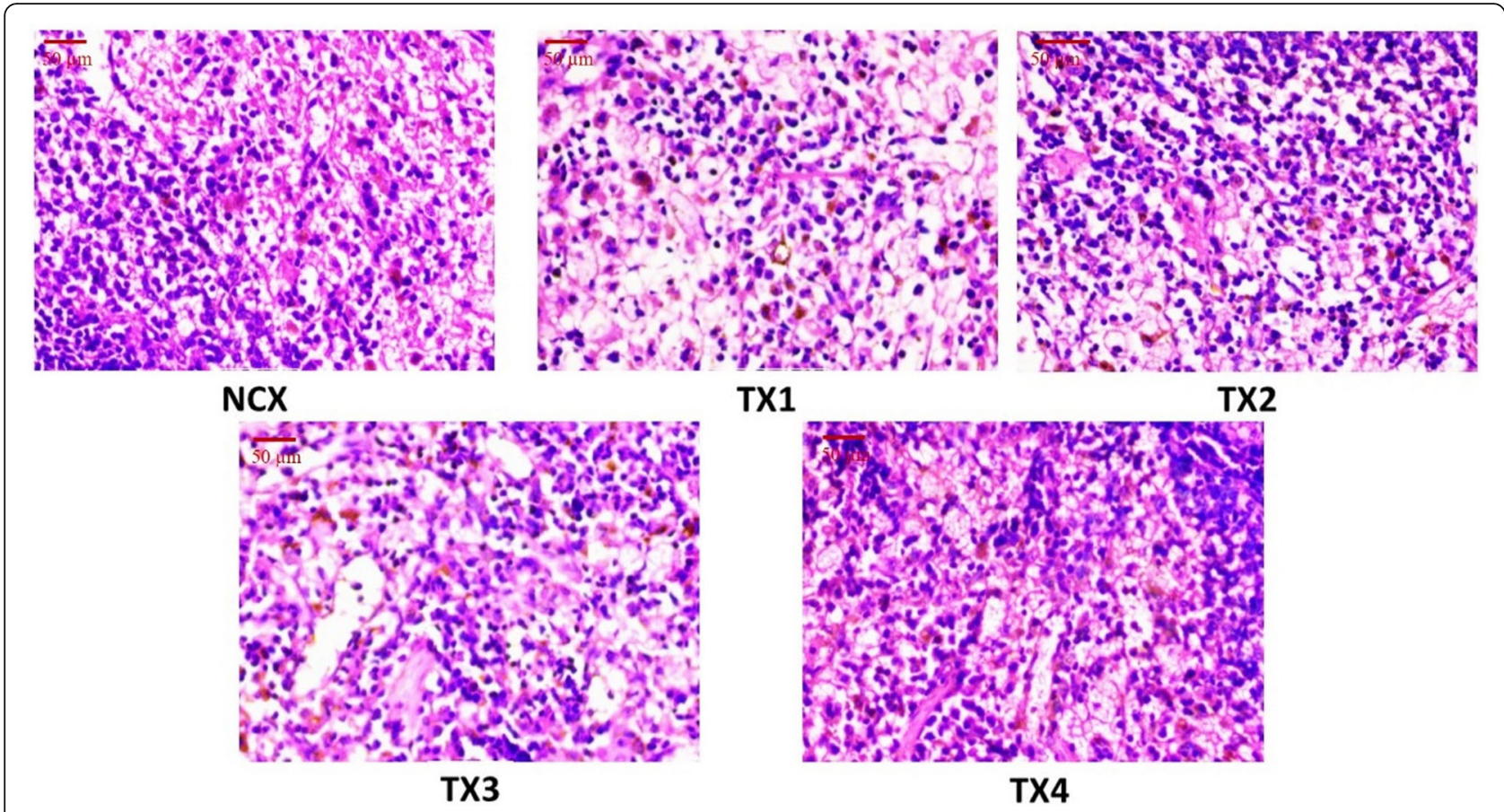

Fig. 6 The histopathology of spleen from the different group of swiss albino mice ( $40 \times$ magnification; Scalar bar: $50 \mu m$ ). No significant damage was observed in the spleen tissue of any treated groups rats. The micropictograph showed the normal white and red pulp areas with no cell breakage in the splenic parenchyma when compared to normal control group (NCX). Where NCX: Normal control group; TX1: Sub-acute toxicity group 1 (250 mg/kg/day/p.o); TX2: Sub-acute toxicity group 2 (500 mg/kg/day/p.o); TX3: Sub-acute toxicity group 3 (1000 mg/kg/day/p.o); TX4: Sub-acute toxicity group 4 (2000 mg/kg/day/p.o)

The PHC seems to be safe at a dose level of $2000 \mathrm{mg} /$ $\mathrm{kg}$, and the $\mathrm{LD}_{50}$ is considered be $>2000 \mathrm{mg} / \mathrm{kg}$. Any pharmaceutical drug or compound with the oral $\mathrm{LD}_{50}$ higher than $1000 \mathrm{mg} / \mathrm{kg}$ could be considered safe [64].

This suggests that the PHC of curcumin, quercetin and rutin is practically non-toxic in single dose of level 2000 $\mathrm{mg} / \mathrm{kg}$ body weight, which are used in the treatment of the chronic disorder are going to be safe and don't have any result on relative organ weight, hematological parameters, lipid profile and biochemical parameters which will be confirmed after its subacute toxicity study. A sub-acute toxicity study was further carried out with doses of 250 $\mathrm{mg} / \mathrm{kg}, 500 \mathrm{mg} / \mathrm{kg}, 1000 \mathrm{mg} / \mathrm{kg}$ and $2000 \mathrm{mg} / \mathrm{kg}$ body weight of PHC as per OECD guideline [65].

Sub-acute toxicity is also termed as repeated dose toxicity study. It provides a distinct idea about harmful effects of test compounds which are activated by frequent exposure and progressive effect which may be due to the cumulative effect of the test substances on the tissues and other parameters [66]. It also helps to find out the concentration of the repeated use of a test substance or any medical compound. This study also provides the information about the effect of test compounds on individual organ at different dose levels [67].

Organ weight are the most sensitive markers of potential effects of drug toxicity, as significant alterations in organ weight between control and treated animals may arise in the absence of any kind of morphological changes [68]. Relative organ weight is a consistent indicator which can be utilized to measure the grade of toxicity of any chemicals or drug as it gives information about the effect of test compound on each organ irrespective of body weight [69]. Many possibilities are there that toxic effect may cause decrease in weight of one organ and simultaneously increasing the weight of other, where body weight remains constant [67].

The hematological analysis is one of the utmost sensitive targets for toxic drugs and chemicals, it serve as an important index of pathological and physiological status in animals and human [70]. Evaluation of haematological parameters could be helpful in defining the toxic effects of the PHC on test animal's blood and therefore can be utilised to explain blood related function of PHC [71]. The haematological outline after treatment with PHC showed results which were mostly non-significant when compared with the normal control and lies within the normal range for experimental animals. This indicates that the administration of $\mathrm{PHC}$ is not able to generate any key toxic effects on the haematological profile of mice.

The analysis of biochemical parameters plays an important role while evaluating the toxic potential of any 


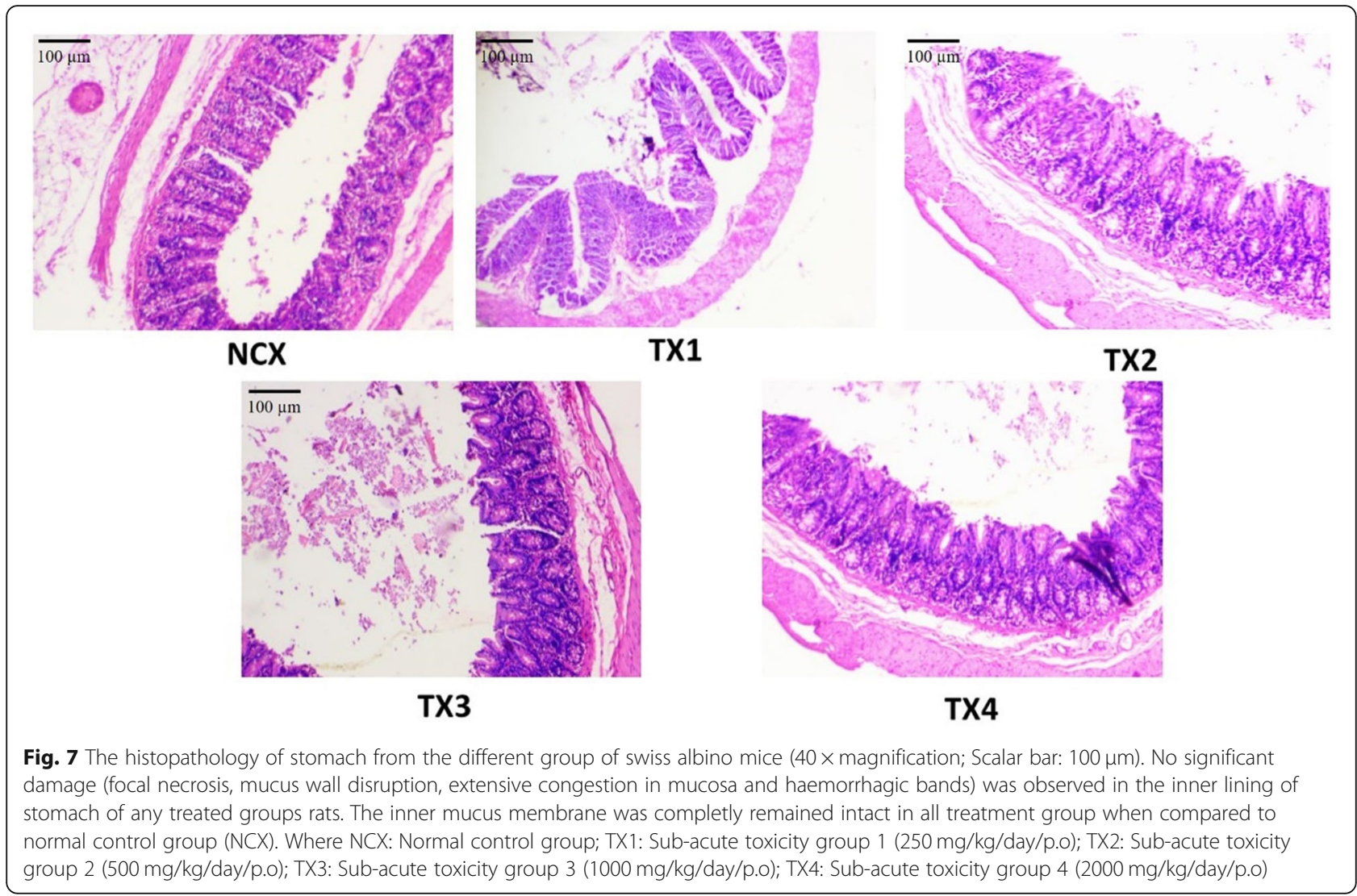

test compound. In fact, biochemical parameters would provide valuable information concerning the specific organs such as liver and kidney which are among the vital organs [72].

Transaminase along with ALP and GGT are assumed as gold marker of inflammation in visceral organs (Liver, heart, kidney). Augmented levels of these marker enzymes are found in liver diseases or hepatotoxicity [73]. The current study reveals no significant variations in the level of biochemical markers. In TX2 group, the level of GGT showed highly significant rise in the level. This change was not considered as toxicologically significant because this effect was inconsistent and dosedependent. This indicates that liver and other organ damage instigated by this PHC can't be suspected; because it was not reciprocated in histopathological image estimations [72].

Proteins are constructive block in every living being, the increase in the body provide signal regarding organ or tissue damage been repaired. Change in total serum total is triggered by a variation in the volume of plasma water and an alteration in the concentration of one or additional explicit proteins in the plasma. Decline in the volume of plasma water (hyperproteinemia) is recorded in cases of dehydration due to because of excessive water loss or inadequate water intake, similar case in observed during severe vomiting or diarrhoea [74]. The result describes that no change in total serum proteins, albumin, globulin and A/G ratio in treated mice may imply absence of liver lesions that might have altered some hepatic functions.

The levels of plasma lipid were significantly decreased in PHC treated groups when compared to normal control group, where, the level of LDL was found to be decreased while the levels of HDL were significantly raised in the treatment groups. This exhibited that the PHC had some beneficial properties which will remove the reducing cardiovascular risk factors thus thereby acting as a protective factor against advances of atherosclerosis and related coronary diseases [75]. Therefore, the results indicate the hypolipidemic effect of $\mathrm{PHC}$ in reducing the lipid profile level, which might be due to the antioxidant properties or presence of hypolipidemic nature of constituent of PHC.

An alteration in kidney function test is measured as significant markers of renal dysfunction [76]. In the present study, there were no significant changes detected in the levels of renal parameters of PHC treated rats when compared to control. However, there was highly significant change in the level of glucose in TX2 group and significant change in level of creatinine in TX3 group when compared to normal control. These changes 


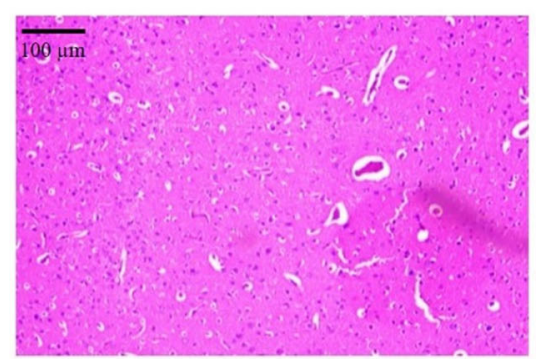

NCX

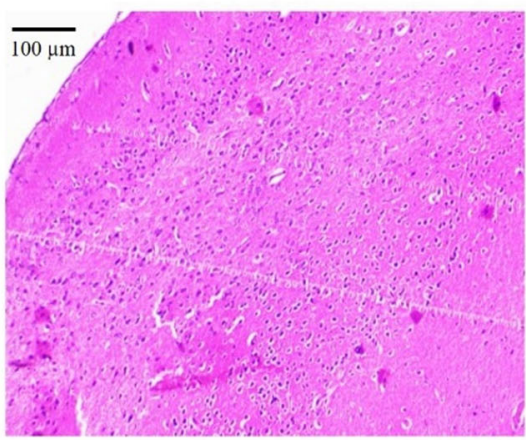

TX3

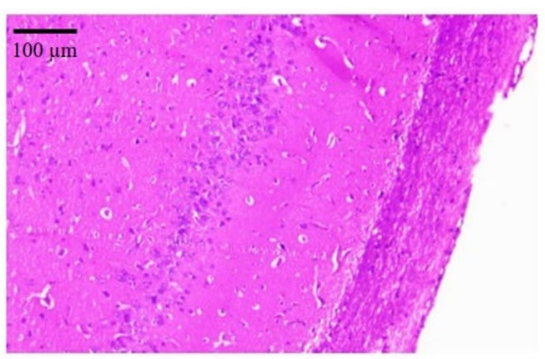

TX1

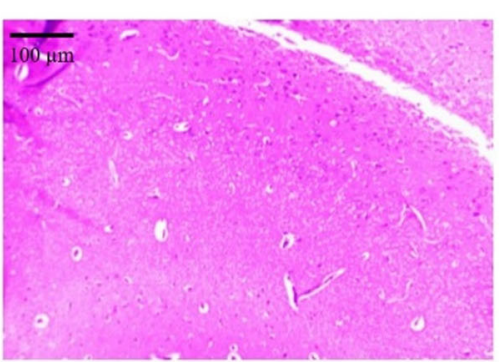

TX2

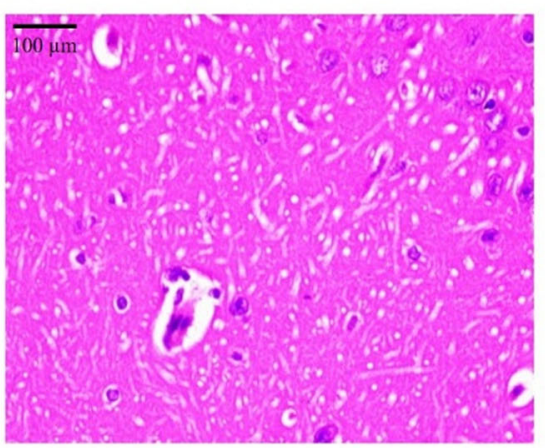

TX4

Fig. 8 The histopathology of brain from the different group of swiss albino mice (40 × magnification; Scalar bar: $100 \mu$ m). No significant damage (ex. neuronal necrosis, neuronophagia, cellular necrosis, intact glial cells) was observed in the brain cells of any treated groups rats. The architecture of brain cells is normal in all experimental groups when compared to normal control group (NCX). Where NCX: Normal control group; TX1: Sub-acute toxicity group 1 (250 mg/kg/day/p.o); TX2: Sub-acute toxicity group 2 (500 mg/kg/day/p.o); TX3: Sub-acute toxicity group 3 (1000 mg/kg/day/p.o); TX4: Sub-acute toxicity group 4 (2000 mg/kg/day/p.o)

were not considered toxic as the effects were dosedependent and were not reciprocated in histopathological analysis. These findings by this means demonstrate the nontoxic effect of PHC on renal function in treated mice when compared to control groups.

SOD is an enzyme which catalyzes the dismutation of two superoxide anions into molecular oxygen and hydrogen peroxide [77]. The reduced level of SOD action may be due to its consistent utilization to shield the cells from the detrimental effects of superoxide radicals. CATALASE (CAT) is identified as a secondary antioxidant enzyme in defence of peroxidative molecules. The increase level of CAT might be attributed to feedback action of hydrogen peroxide on the mRNA expression. GPx is the chief antioxidant which is responsible for removal of hydrogen peroxide formed during the dismutation of superoxide radicals through consuming reduced glutathione. As GPx eradicates the excess hydrogen peroxide molecules, there is an increase in consumption of reduced glutathione. Deficiency or Lack of glutathione leads to reduction in the plasma level of GPX [78].

Therefore, antioxidant enzyme status of the experimental animals was studied subsequent to the administration of PHC. Almost no variations were detected in the blood SOD, GSH, GPx and CATALASE except level of GSH in TX3 group, this rise in GSH level was considered as non-toxic as the level of rise was non-consistent and may be due to variability in animal physiology, the effect was also not confirmed by histopathological examinations. Based on these conclusions, it could be proposed that normal hepatorenal enzymatic antioxidant mechanisms were maintained during PHC administration and do not possess toxicity effects.

This study provides an information on the acute and subacute toxicity profile of the PHC of Curcumin, Quercetin and Rutin that ought to be very helpful for any future in-vivo and clinical study. PHC was found to be non-toxic when oral acute and sub-acute toxicities in mice were performed. These results signified that the $\mathrm{PHC}$ of curcumin, quercetin and rutin is safe and further clinical trial can be done to establish its toxicity clinically.

\section{Conclusion}

Results from this screening provides important evidence and data on toxicological properties of PHC constituted from curcumin, quercetin and rutin, these constituents are extensively used in traditional system of medicine. In the assessment of acute toxicity, oral administration of PHC at a dose up to $2000 \mathrm{mg} / \mathrm{kg}$ b.wt., does not 
displayed any major toxicological symptoms in respect of behavioural, physical and hypersensitivity. In the subacute study, no treatment-related toxicity was seen during the study when rats were administered with PHC up to a maximum dose of $500 \mathrm{mg} / \mathrm{kg}$ b.wt., for a duration of 28 days. Nearly all the evaluations parameters were normal without showing any major variations, these findings were validated by the histopathological studies where no major changes in the architecture of the visceral organs were reported. No mortality was reported in single or multiple dose toxicity study thus implying that the $\mathrm{LD}_{50}$ of the PHC is higher than $2000 \mathrm{mg} / \mathrm{kg}$ b.wt and safe for further use. However, further screening is required to examine and approve its effectiveness and safety in humans.

\section{Abbreviations}

WHO: World Health Organization; FDA: Food and Drug Administration; NOAEL: No observed adverse effect level; OECD: Organisation for Economic Co-operation and Development; PHC: Polyherbal combination; CDRI: Central Drug Research Institute; $\mathrm{ED}_{50}$ : Effective dose; NC: Normal control group of acute toxicity; TG1: Toxic group 1 of acute toxicity; TG2: Toxic group 2 of acute toxicity; TG3: Toxic group 3 of acute toxicity; TG4: Toxic group 4 of acute toxicity; NCX: Normal control group of sub-acute toxicity; TX1: Subacute toxicity group 1; TX2: Sub-acute toxicity group 2; TX3: Sub-acute toxicity group 3; TX4: Sub-acute toxicity group 4; RBC: Red blood corpuscle count; Hb: Hemoglobin; HCT: Hematocrit; PLT: Platelet count; WBC: White blood corpuscle count; DLC: Differential Leukocyte Count; PCV: Packed cell volume; MCV: Mean corpuscular volume; MCH: Mean corpuscular haemoglobin; MCHC: Mean corpuscular hemoglobin concentration; SGPT: Serum Glutamic Pyruvate transaminase; ALT: Alanine Transaminase; SGOT: Serum Glutamic Oxaloacetic Transaminase (SGOT); AST: Aspartate aminotransferase; ALP: Serum Alkaline Phosphatase; GGT: Gamma-glutamyl transferase; TP: Total protein; Alb: Albumin; Glb: Globulin; BUN: Blood Urea Nitrogen; TChol: Total cholesterol; TG: Triglyceride; LDL: Low density lipoprotein; HDL: High density lipoprotein; VLDL: Very low-density lipoprotein GSH: Reduced glutathione; CAT: Catalase; SOD: Superoxide dismutase; GPx: Glutathione peroxidase; ANOVA: Analysis of variance; A/G ratio: Albumin Globulin ratio

\section{Acknowledgments}

Author thanks the management of Singhania University, Rajasthan for enrollment in the esteemed institute for pursuing doctoral degree. Author extends his heartful gratitude toward Prof. Syed Waseem Akhtar, Hon. Chancellor and Prof. Aqil Ahmad, Hon. Vice Chancellor of Integral University for providing excellent workplace and research facility in the university. The university has provided a manuscript communication number for further communication (IU/R\&D/2020/MCN000911).

\section{Authors' contributions}

The research work was performed by RT, the work was designed by MHS and TM, AF helped in performing the experimental work, PB assisted the analysis of various parameters though UV and HPLC. FA was involved in preparation and formatting of manuscript and AS helped in performing animal activity. The author(s) read and approved the final manuscript.

\section{Funding}

$\mathrm{NIL}$

\section{Availability of data and materials}

All data concerned to this research has been mentioned in this manuscript, no supplementary data has been uploaded.

\section{Ethics approval and consent to participate}

The protocol followed during this study was reviewed and approved by Institutional Animal Ethical Committee (IAEC), Faculty of Pharmacy, Integral University, and Lucknow (Reg no. 1213/PO/Re/S/08/CPCSEA, 5th June 2008) having approval no. IU/IAEC/19/02. The present study was conducted at the departmental animal house, faculty of pharmacy, Integral University as per good laboratory practices (GLP) and test guidelines of the OECD guideline.

\section{Consent for publication}

No data were selected from other research work, no consent required.

\section{Competing interests}

The authors declare no potential conflicts of interest with respect to the research, authorship, and/or publication of this article.

\section{Author details}

'Department of Pharmaceutics, Faculty of Pharmacy, Integral University, Lucknow, India. ${ }^{2}$ Research Scholar, Singhania University, Pacheri Bari, Jhunjhunu, Rajasthan, India. ${ }^{3}$ Department of Bioengineering, Faculty of Engineering, Integral University, Lucknow, India. ${ }^{4}$ Department of Pharmacology, Faculty of Pharmacy, Integral University, Lucknow, India. ${ }^{5}$ Former Faculty member, Department of Pharmacy, Integral University, Lucknow, India.

Received: 19 June 2020 Accepted: 10 November 2020

Published online: 04 December 2020

\section{References}

1. Tilburt J, Kaptchuk T. Herbal medicine research and global health: an ethical analysis. Bull World Health Organ. World Health Organization. 2008;86:594-9.

2. Balunas MJ, Kinghorn AD. Drug discovery from medicinal plants. Life Sci. 2005:78:431-41.

3. Qazi M, Molvi K. Herbal medicine: a comprehensive review. Int J Pharm Res. 2016;8:1-5.

4. Parasuraman S. Toxicological screening. J Pharmacol Pharmacother. 2011;2: 74-9.

5. Ghosh D, Mondal S, Ramakrishna K. Acute and sub-acute (30-day) toxicity studies of Aegialitis rotundifolia Roxb., leaves extract in Wistar rats: safety assessment of a rare mangrove traditionally utilized as pain antidote. Clin Phytoscience. 2019:5:1-16.

6. Arome D, Chinedu E. The importance of toxicity testing. J Pharm Biosci. 2013:4:146-8.

7. Teke GN, Kuete V. Acute and subacute toxicities of African medicinal plants. Toxicol Surv Afr Med Plants. 2014;2:63-98.

8. Dubey NK, Kumar R, Tripathi P. Global promotion of herbal medicine: India's opportunity. Curr Sci. 2004;86:37-41.

9. Middleton E, Kandaswami C. Theoharides T. The effects of plant flavonoids on mammalian cells: implications for inflammation, heart disease, and cancer. Pharmacol Rev. 2000:52:673-751.

10. Williams RJ, Spencer JPE, Rice-Evans C. Flavonoids: antioxidants or signalling molecules? Free Radic Biol Med. 2004:3:838-49.

11. Rasmussen SE, Frederiksen H, Struntze Krogholm K, Poulsen L. Dietary proanthocyanidins: occurrence, dietary intake, bioavailability, and protection against cardiovascular disease. Mol Nutr Food Res. 2005;49:159-74.

12. Ramassamy C. Emerging role of polyphenolic compounds in the treatment of neurodegenerative diseases: a review of their intracellular targets. Eur J Pharmacol. 2006;545(1):51-64.

13. Bláha L, Kopp R, Simková K, Mares J. Oxidative stress biomarkers are modulated in silver carp (Hypophthalmichthys molitrix Val.) exposed to microcystin-producing cyanobacterial water bloom. Acta Vet Brno. 2004;73: 477-82.

14. Dias A, Porawski M, Alonso M, Marroni N. Quercetin decreases oxidative stress, NF-KB activation, and iNOS overexpression in liver of streptozotocininduced diabetic rats. J Nutr. 2005;135:2299-304.

15. Asher GN, Spelman K. Clinical utility of curcumin extract. Altern Ther Health Med. 2013;19:20-2.

16. Marchiani A, Rozzo C, Fadda A, Delogu G, Ruzza P. Curcumin and Curcuminlike molecules: from spice to drugs. Curr Med Chem. 2014;21:204-22.

17. Aggarwal ML, Chacko KM, Kuruvilla BT. Systematic and comprehensive investigation of the toxicity of curcuminoid-essential oil complex: a bioavailable turmeric formulation. Mol Med Rep. 2016;13:592-604.

18. Sittisomwong $N$, Leelasangaluk $V$, Chivapat $S$, Wangmad A, Ragsaman $P$, Chuntarachaya C. Acute and subchronic toxicity of turmeric. Bull Dep Med Sci. 1990:32:101-11. 
19. Mohammed A, Alhassan AJ, Ibrahim M, Mohammed A, Wudil AM, Alhassan AJ, et al. Acute and subchronic toxicity studies of aqueous, methanolic and $\mathrm{n}$-Hexane root extracts of Curcuma longa L. on albino rats. Br J Pharm Res. 2016;14:1-8.

20. Srimal RC, Dhawan BN. Pharmacology of diferuloyl methane (curcumin), a non-steroidal anti-inflammatory agent. J Pharm Pharmacol. 1973:25:447-52.

21. Harborne J. Nature, distribution and function of plant flavonoids. Prog Clin Biol Res. 2013;213:15-24

22. Havsteen B. Flavonoids, a class of natural products of high pharmacological potency. Biochem Pharmacol. 1983;32:1141-8.

23. Suzuki T, Morishita T, Noda T, Ishiguro K. Acute and subacute toxicity studies on Rutin-rich Tartary buckwheat dough in experimental animals. J Nutr Sci Vitaminol. 2015;61:175-81.

24. Hasumura M, Yasuhara K, Tamura T, Imai T, Mitsumori K, Hirose M. Evaluation of the toxicity of enzymatically decomposed rutin with 13-weeks dietary administration to Wistar rats. Food Chem Toxicol. 2004;42:439-44.

25. Patil S, Somashekarappa H, Rajashekhar K. Evaluation of the radioprotective action of rutin in mice exposed to gamma-radiation. Int J Biol Pharm Res. 2012;3:12-8

26. Morand C, Manach C, Crespy V, Remesy C. Respective bioavailability of quercetin aglycone and its glycosides in a rat model. BioFactors. 2000;12(14):169-74.

27. Harwood M, Danielewska-Nikiel B, Borzelleca JF, Flamm GW, Williams GM, Lines TC. A critical review of the data related to the safety of quercetin and lack of evidence of in vivo toxicity, including lack of genotoxic/carcinogenic properties. Food Chem Toxicol. 2007;45:2179-205.

28. Ruiz MJ, Fernández M, Estela JM, Asensi MÁ, Mañes J, Picó Y. Short-term oral toxicity of quercetin and pterostibene in Swiss mice. Toxicol Lett. 2006;164: S275-6.

29. Agarwal OP. The anti-inflammatory action of nepitrin, a flavonoid. Agents Actions. 1982;12:298-302.

30. Della Loggia R, Tubaro A, Dri P, Zilli C, Del Negro P. The role of flavonoids in the antiinflammatory activity of Chamomilla recutita. Prog Clin Biol Res. 1986;213:481-4.

31. Ferrándiz ML, Alcaraz MJ. Anti-inflammatory activity and inhibition of arachidonic acid metabolism by flavonoids. Agents Actions. 1991;32:283-8.

32. Emim JADS, Oliveira AB, Lapa AJ. Pharmacological evaluation of the antiinflammatory activity of a citrus bioflavonoid, hesperidin, and the Isoflavonoids, Duartin and Claussequinone, in rats and mice. J Pharm Pharmacol. 1994:46:118-22.

33. Di Carlo G, Mascolo N, Izzo AA, Capasso F. Flavonoids: old and new aspects of a class of natural therapeutic drugs. Life Sci. 1999:65(4):337-53.

34. OECD/OCDE 425. OECD guidelines for the testing of chemicals, section 4, test no. 425: acute oral toxicity - up-and-down procedure. Guidel Test Chem. 2001;26:1-21.

35. OECD/OCDE 407. OECD guidelines for the testings of chimicals repeated dose 28-day oral toxicity study in rodents. Guidel Test Chem. 2006;1:1-11.

36. Han CT, Kim MJ, Moon SH, Jeon YR, Hwang JS, Nam C, et al. Acute and 28day subacute toxicity studies of hexane extracts of the roots of Lithospermum erythrorhizon in Sprague-dawley rats. Toxicol Res. 2015;31:403-14.

37. Lee J-M, Lee M-A, Do H-N, Song Y-I, Bae R-J-N, Lee H-Y, et al. Historical control data from 13-week repeated toxicity studies in Crj:CD (SD) rats. Lab Anim Res. 2012;28:115.

38. Olson MJ, Johnson JT, Reidy CA. A comparison of male rat and human urinary proteins: implications for human resistance to hyaline droplet nephropathy. Toxicol Appl Pharmacol. 1990;102:524-36.

39. Balogun FO, Tom Ashafa AO. Acute and subchronic oral toxicity evaluation of aqueous root extract of Dicoma anomala Sond. in Wistar Rats. Prieto JM, editor. Evidence-Based Complement Altern Med. 2016:2016:3509323.

40. Afolabi SO, Akindele AJ, Awodele O, Anunobi CC, Adeyemi OO. A 90 day chronic toxicity study of Nigerian herbal preparation DAS-77 in rats. BMC Complement Altern Med. BioMed Central. 2012;12:1165.

41. Ahsan F, Mahmood T, Siddiqui MH, Usmani S, Bagga P, Shamim A, et al. Diligent profiling of preclinical safety of the silk protein sericin. J Basic Clin Physiol Pharmacol. 2020;1 (e-pub ahead).

42. Pennock CA, Murphy D, Sellers J, Longdon KJ. A comparison of autoanalyser methods for the estimation of glucose in blood. Clin Chim Acta. 1973;48: 193-201.

43. Gokarn RA, Nariya MB, Patgiri BJ, Prajapati PK. Toxicological studies of Rasasindura, an ayurvedic formulation. Indian J Pharm Sci. 2017;79:633-40.
44. Wilkinson $J H$, Boutwell JH, Winsten S. Evaluation of a new system for the kinetic measurement of serum alkaline phosphatase. Clin Chem. 1969;15: 487-95.

45. Fossati P, d'Eril GVM, Tarenghi G. A kinetic colorimetric assay of $\gamma$ glutamyltransferase. Clin Chem. 1986;32:1581-4.

46. Ryan M, RK C. Biuret method of protein determination. Biochem Biophys Acta. 1976;427:337-49.

47. Doumas BT, Ard Watson W, Biggs HG. Albumin standards and the measurement of serum albumin with bromcresol green. Clin Chim Acta. 1971;31:87-96.

48. Doumas BT, Perry BW, Sasse EA, Straumfjord JV. Standardization in bilirubin assays: evaluation of selected methods and stability of bilirubin solutions. Clin Chem. 1973:19:984-93.

49. Fawcett JK, Scott JE. A rapid and precise method for the determination of urea. J Clin Pathol. 1960:13:156-9.

50. Blass K, Thibert R, Lam L. A study of the mechanism. Z Klin Chem Klin Biochem. 1974:12:336-43.

51. Dodge JT, Mitchell C, Hanahan DJ. The preparation and chemical characteristics of hemoglobin-free ghosts of human erythrocytes. Arch Biochem Biophys. 1963;100:119-30.

52. Moron MS, Depierre JW, Mannervik B. Levels of glutathione-S-transferase activities in rat lung and liver. Biochim Biophys Acta. 1979;582:67-78.

53. Beers RF, Sizer IW. A spectrophotometric method for measuring the breakdown of hydrogen peroxide by catalase. J Biol Chem. 1952;195:13340.

54. Misra H, Fridovich I. The role of superoxide anion in the autoxidation of epinephrine and a simple assay for superoxide dismutase* ${ }^{*}$ J Biol Chem. 1972;247:317-3175.

55. Rotruck JT, Pope AL, Ganther HE, Swanson AB, Hafeman DG, Hoekstra WG. Selenium: biochemical role as a component of glatathione peroxidase. Science. 1973;179:588-90.

56. Kifayatullah M, Waheed I, Das SK, Sisugoswomi M, Izharullah. Evaluation of hydroethanolic extract of Opuntia monacantha Haw. for analgesic activity. World J Pharm Pharm Sci. 2014:3:1006-20

57. Vaghasiya YK, Shukla VJ, Chanda SV. Acute oral toxicity study of pluchea arguta boiss extract in mice. J Pharmacol Toxicol. 2010;6:113-23.

58. Mythilypriya R, Shanthi P, Sachdanandam P. Oral acute and subacute toxicity studies with Kalpaamruthaa, a modified indigenous preparation, on rats. J Health Sci. 2007;53:351-8.

59. Sushruta K, Satyanarayana S, Srinivas S, Sekhar JR. Evaluation of the bloodglucose reducing effects of aqueous extracts of the selected Umbelliferous fruits used in culinary practices. Trop J Pharm Res. 2007:5:613-7.

60. Sultana N, Alsarhan A, Al-Khatib A, Kadir M. Review on some Malaysian traditional medicinal plants with therapeutic properties. J Basic Appl Sci. 2014;10:149-59.

61. Hayes A, Kruger C. Hayes' principles and methods of toxicology. New York: Crc Press; 2014

62. Ukwuani AN, Abubakar MG, Hassan SW, Agaie BM. Toxicological studies of Hydromethanolic leaves extract of Grewia crenata. Int J Pharm Sci Drug Res. 2012:4:249.

63. Wang J, Sun F, Tang S, Zhang S, Lv P, Li J, et al. Safety assessment of vitacoxib: acute and 90-day sub-chronic oral toxicity studies. Regul Toxicol Pharmacol. 2017:86:49-58.

64. Adeneye AA, Olagunju JA. Preliminary hypoglycemic and hypolipidemic activities of the aqueous seed extract of Carica papaya Linn. in Wistar rats. Biol Med. 2009;1:1-10.

65. Kunimatsu T, Yamada T, Miyata K, Yabushita S, Seki T, Okuno Y, et al. Evaluation for reliability and feasibility of the draft protocol for the enhanced rat 28-day subacute study (OECD guideline 407) using androgen antagonist flutamide. Toxicology. 2004;200:77-89.

66. Abbott LC. Selecting optimal animal models to investigate environmental toxicology. Poultry Fish Wildl Sci. 2013;1:e102-2103.

67. Donkor K, Okine LNK, Abotsi WK, Woode E. Acute and sub-chronic toxicity studies of aqueous extract of root bark of Cassia Sieberiana D.C. in rodents. J Appl Pharm Sci. 2014;4:84-9.

68. Piao $Y$, Liu $Y$, Xie $X$. Change trends of organ weight background data in Sprague Dawley rats at different ages. J Toxicol Pathol. 2013; 26:29-34

69. Arsad S, Mohd EN, Hamzah H, Othman F. Evaluation of acute, subacute and subchronic oral toxicity of Rhaphidophora decursiva 
(Roxb.) Schott extract in male Sprague Dawley rats. J Med Plant Res. 2013;7:3030-40.

70. Mukinda JT, Syce JA. Acute and chronic toxicity of the aqueous extract of Artemisia afra in rodents. J Ethnopharmacol. 2007:112:138-44.

71. Yakubu, Akanji M, Oladiji A. Hematological evaluation in male albino rats following chronic administration of aqueous extract of Fadogia agrestis stem. Pharmacogn Mag. 2020;3(9):38.

72. Nfozon JN, Tume C, Kdjo N, Boyom FF, Leonard SF, Dzoyem JP, et al. Acute and sub-chronic toxicity evaluation of triplotaxis stellulifera (Benth.) hutch and crasssocephalum bougheyanum C. D. Adams methanol extract on mice. Biochem Anal Biochem. 2019;8(3):391.

73. Ramaiah SK. Preclinical safety assessment: current gaps, challenges, and approaches in identifying translatable biomarkers of drug-induced liver injury. Clin Lab Med. 2011;31:161-72.

74. Féres CAO, Madalosso RC, Rocha OA, Leite JPV, Guimarães TMDP, Toledo VPP, et al. Acute and chronic toxicological studies of Dimorphandra mollis in experimental animals. J Ethnopharmacol. 2006:108:450-6.

75. Sundaram R, Karuppaiah M, Shanthi P, Sachdanandam P. Acute and sub acute studies of catechol derivatives from Semecarpus anacardium. Toxicol Rep. 2018;5:231-9.

76. Ibrahim MY, Abdul AB, Tengku Ibrahim TA, Abdelwahab SI, Elhassan Taha MM, Syam MM. Evaluation of acute toxicity and the effect of single injected doses of zerumbone on the kidney and liver functions in Sprague Dawley rats. Afr J Biotechnol. 2010;9(28):9-17.

77. Momen Beitollahi J, Mansourian A, Momen Heravi F, Amanlou M, Obradov S, SahebJamee M. Assessment of salivary and serum antioxidant status in patients with recurrent aphthous stomatitis. Med Oral Patol Oral Cir Bucal. 2010;15(4):8-15.

78. Karincaoglu Y, Batcioglu K, Erdem T, Esrefoglu M, Genc M. The levels of plasma and salivary antioxidants in the patient with recurrent aphthous stomatitis. J Oral Pathol Med. 2005;34(1):7-12.

\section{Publisher's Note}

Springer Nature remains neutral with regard to jurisdictional claims in published maps and institutional affiliations.

\section{Submit your manuscript to a SpringerOpen ${ }^{\circ}$ journal and benefit from:}

- Convenient online submission

- Rigorous peer review

- Open access: articles freely available online

- High visibility within the field

- Retaining the copyright to your article

Submit your next manuscript at $\boldsymbol{\nabla}$ springeropen.com 